Article

\title{
Fuzzy Model for Selecting a Form of Use Alternative for a Historic Building to be Subjected to Adaptive Reuse
}

\author{
Małgorzata Fedorczak-Cisak*D, Alicja Kowalska-Koczwara *, Filip Pachla ${ }^{\mathbb{D} \text {, }}$ \\ Elżbieta Radziszewska-Zielina ${ }^{\mathbb{D}}$, Bartłomiej Szewczyk*(D), Grzegorz Śladowski and \\ Tadeusz Tatara \\ Faculty of Civil Engineering, Cracow University of Technology, 31-154 Krakow, Poland; fpachla@pk.edu.pl (F.P.); \\ eradzisz@izwbit.wil.pk.edu.pl (E.R.-Z.); gsladowski@l7.pk.edu.pl (G.Ś.); ttatara@pk.edu.pl (T.T.) \\ * Correspondence: mfedorczak-cisak@pk.edu.pl (M.F.-C.); akowalska@pk.edu.pl (A.K.-K.); \\ bszewczyk@17.pk.edu.pl (B.S.); Tel.: +48-6960-460-50 (M.F.-C.)
}

Received: 24 April 2020; Accepted: 28 May 2020; Published: 1 June 2020

check for updates

\begin{abstract}
Adapting historic buildings to new, modern forms generates not only financial benefits for developers but can also allow them to survive for future generations through proper remodelling. The variety of decision criteria related to the selection of a new function of a historic building makes this problem multidimensional. Many of these criteria are interrelated and have a non-linear nature which requires a comprehensive network-based rather than a classic hierarchical approach to conducting multi-criteria analysis. A comprehensive approach taking into account the specificity of the analysed problem was proposed. The study was supported by an example of the choice of building function as part of the adaptive reuse of a historic building located in Zakopane. The following variants have been analysed: a hostel (existing state), a five-star hotel, a folk art gallery and a conference and training centre. The final rating of alternatives indicates that the hotel best meets the adopted decision criteria.
\end{abstract}

Keywords: historical buildings; sustainable development; multi-criteria analysis; fuzzy weighted influence non-linear gauge system-FWINGS; fuzzy sets; thermal comfort

\section{Introduction}

The majority of historic buildings do not fulfil their original functions, because the progress of civilization has forced changes in the way of using them for modern needs. Extending the life cycle of historical buildings by changing the way they are used can generate not only financial benefits for developers, but also other benefits like: societal benefits, environmental protection or cultural heritage benefits, which are important from the point of view of sustainable development $[1,2]$. This may apply to historic buildings under conservation, regardless of the function they currently perform (e.g., residential, commercial).

The selection of new forms of use for a historical building is difficult and complex because of the necessity to consider numerous factors (criteria) that are interdisciplinary in character. This complex process of multi-criteria decision-making requires decision-makers to work with data that is both measurable (e.g., technical and financial data associated with a historical structure), as well as difficult-to-measure information (e.g., the value of the cultural heritage of a historical site, benefits to society).

It should be noted that decisions always have the character of a number in order for a decision-maker to be able to choose a variant or a group thereof from a selection of appropriately 
numbered alternatives [3]. In light of the above, the aforementioned type of information about a building should be transformed into numerical values, despite the fact that we can find critical opinions among the conservation community concerning attempts to express the characteristics of a heritage site using numbers during its evaluation. However, in the field of architectural conservation there are many numerical systems used in assessing and rating heritage, of which an excellent example is the instruction by Vicq d'Azyr of 1793 [4]. The problem of making decisions as to the future fate of a historical building is a stimulus to search for objective methods of selecting values that describe heritage sites as well as methods of assessing them [3].

In the field of architectural conservation, numerous authors, e.g., [3] or [5,6] proposed using multi-criteria decision analysis methods (that are widely used in other fields as well) for this purpose $[7,8]$. These methods, based on expert opinions, make it possible to process data concerning the values of attributes and indicators describing a historical building, in addition to taking into consideration a set of possible decision alternatives with their own set of defined characteristics. All of these elements are presented in a synthetic manner as either a hierarchical or network-based dependence (relationship) model that determines the direction or the manner of analysis performance. This makes it possible to combine and simultaneously process qualitative and quantitative information. Some of the algorithms of these methods feature procedures that control the coherence of expert opinions and that make it possible to formulate group expert opinions, often on the subject of values that have an interdisciplinary character.

In the literature we can find decision-making models associated with: evaluating historical buildings [6] or [9], the need to classify them [10] or [11], with establishing priorities of financing and carrying out various types of work on historical structures, e.g., [12-14]. We can also find analyses that are associated with spatial planning in the context of protecting historical buildings $([9,15-17])$ or decision-making models used for the purpose of selecting conservation technology and the type of conservation materials ([18-21]).

Considering multi-criteria analysis of a new form of use in the adaptive reuse of historical buildings was pointed out by [5], who studied historical building revitalisation in Vilnius, Lithuania. They proposed the use of the TOPSIS (technique for order preference by similarity to an ideal solution) method as a multi-criteria analysis tool for forms of use during adaptation. A fuzzy extension of the TOPSIS method for the aforementioned purposes was developed and continued in [22,23]. Fuentes [24] in turn used the weighted sum method in assessing the possibility of reusing four historical buildings in Spain. Wang and Zeng [25] analysed alternatives of forms of use in the adaptation of two historical structures in Taipei, Taiwan. They employed a structural modelling method known as ANP (analytic network process) as their multi-criteria analysis tool. Breil, Giove, and Rosato [26] and Giove, Rosato and Breil [27], focusing on selecting a new form of use for the Arsenal building in Venice, Italy, employed the "Choquet" integral to perform a multi-criteria analysis of this process. Ferretti, Bottero, and Mondini [28] proposed an interesting approach in investigating the possibility of using multi-attribute value theory (MAVT) in analysing preferences for historical buildings in Turin in terms of fulfilling a specific forms of use. Lately, Radziszewska-Zielina and Śladowski [29] proposed a fuzzy extension of the WINGS (weighted influence non-linear gauge system) method. Using this method, they addressed the imprecision, incompleteness and uncertainty of information to be processed by experts during the selection of a new form of use on the example of the Great Armoury, a historic building in Gdańsk, Poland.

The above-mentioned models and methods of multi-criteria analysis of a form of use alternative selection in the adaptation of historical buildings have significant limitations. First, most researchers in the aforementioned approaches do not account for the relationships between the criteria and decision alternatives, although the nature of the criteria often shows a relationship between them (e.g., financial aspects related to an a building's adaptive reuse alternative affect aspects correlated with the energy efficiency and vice versa). Second, not adopting a hierarchical decision model structure in the form of use selection problems analysed in the literature did not allow bilateral relations (in the form of 
feedback) between criteria and decision alternatives to be accounted for. For example, the criterion of aspects of the protection of cultural heritage negatively impacts adapting the building to a hotel, as it can considerably hinder this function. The influence of this criterion on an art gallery will be different. Until now, only the influence of alternatives on criteria in the sense of the degree to which a given adaptation alternative fulfils the purpose defined by the criterion has been considered in the literature.

The hierarchical approach to the problem is, therefore, not universal and is rather a special case considering the frequently occurring relationships between criteria and decision alternatives. Therefore, a network-based problem structure should be the starting point for modelling the relationship between criteria and decision alternatives.

Third, none of the proposed approaches account for whether the relationship between the criteria themselves as well as the relationship between criteria and alternatives is positive or negative, which may have a significant influence on analysis results. For example, the criterion of cultural heritage protection negatively influences the financial criterion (profitability index), because increasing the degree to which cultural heritage is protected requires additional cost (e.g., more conservation work).

Fourth, it is necessary to develop more precise ways of modelling uncertain expert assessments as an input to the analysis and minimising their subjective character. To address these shortcomings, the authors of this article propose a new approach to the analysis of the decision problem of selecting a form of use for the adaptive reuse of historical buildings.

The purpose of the article is to present a proposal of an innovative multi-criteria approach to analyse the selection of forms of use for a historical building, which is useful at the stage of preliminary feasibility studies of their adaptive reuse. The multi-criteria approach developed by the authors includes:

- proposing decision criteria compatible with the idea of sustainable development and typical for the analysed problem, while maintaining their universality (based on [29-31]);

- specificity of relationships (network structure of the decision model) both within the criteria set (based on [29]) and the relationship between the said criteria with decision alternatives in the form of feedback (original work);

- accounting for both the negative and positive nature of the aforementioned relationships (original work);

- modelling the uncertainty of expert opinions on the input data for analysis (using fuzzy logic, based on [29]);

- $\quad$ aggregation of fuzzy expert assessments to eliminate their subjective nature (original work);

- operational verification of the approach on the example of the selection of a form of use in the adaptive reuse project of the "Stara Polana" historic building located in Zakopane (original work).

The multi-criteria decision problem:

Following the paradigms of sustainable development, the authors adopted the following assessment criteria, as illustrated in Figure 1 [30,32]:

- $\quad$ energy efficiency (F1)

- building quality (F2)

- $\quad$ comfort of the building (F3)

- the building's environmental impact (F4)

- financial aspects (F5)

- $\quad$ social aspect (F6)

- cultural heritage (F7) 


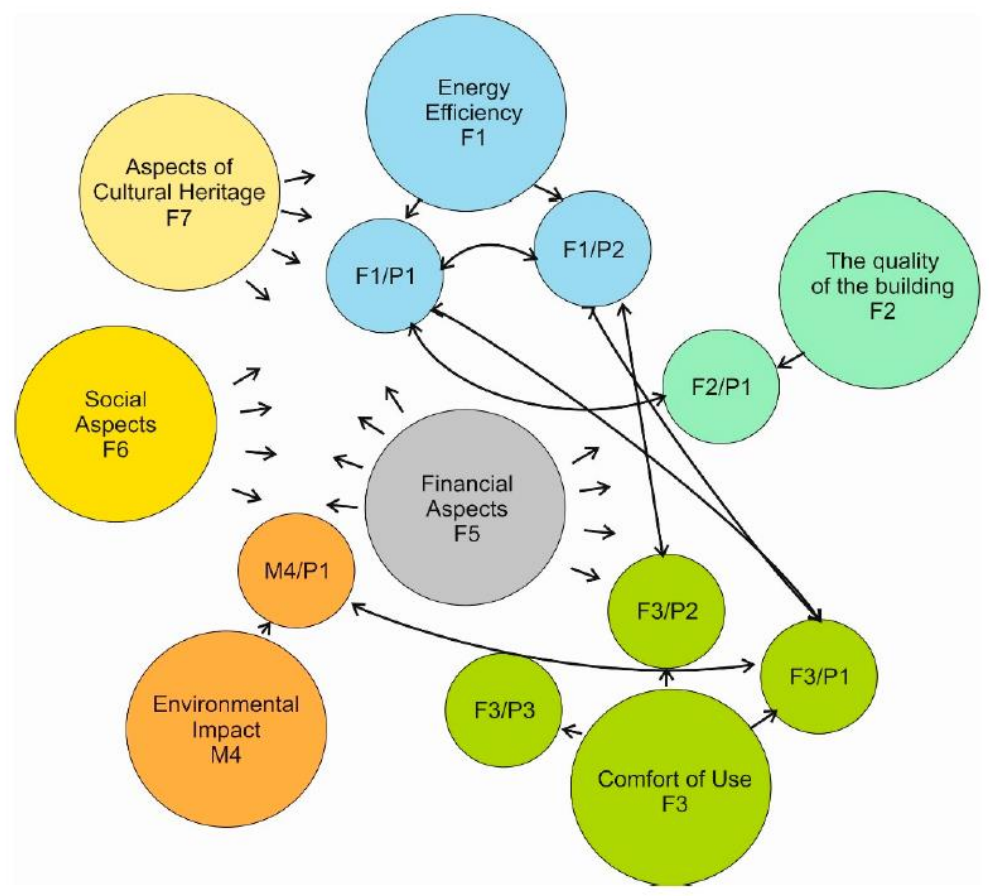

Figure 1. Proposed criteria/sub-criteria and their mutual relationships, as defined for the purposes of choosing a new form of use for the 'Stara Polana' building, based on [31].

The research problem solved by the authors is as follows: is it possible to obtain an optimal new form of use of a historic building that is to be modernised on the basis of the adopted model, a multi-criteria analysis, and the criteria assumed?

\section{Materials and Methods}

\subsection{Method Proposal}

In the literature we can find numerous modelling and structural analysis approaches that have been applied to a series of decision-making problems, the most well-known and effective of which are ANP (fuzzy analytic network process) [33], DEMATEL (decision-making trial and evaluation laboratory) [34] and WINGS developed by Michnik [8]. These methods use directed graphs to model dependencies between the elements of a system. In such graphs, vertices symbolise the elements of a system and arches determine the relationships (influence) between elements. The procedure of modelling the structure of a system and its analysis in all of the methods that have been mentioned is based on similar algebraic mechanisms. Input rating values are entered into a matrix, in which the sum of all exponents in the liminal sense returns input values in the analysed model. Considering that all of the aforementioned methods have the same formal foundations and lead to similar results, the essential factor that determines the selection of the method with which to perform the multi-criteria analysis of the problem presented in this work is their usefulness. In these terms, the DEMATEL and WINGS methods appear to be better because input rating values are introduced into the matrix directly, based on a special ratings scale $[32,35]$ contrary to the labour-intensive and problematic procedure of pairwise comparisons used in the ANP method. Of note are also the technical capabilities of performing calculations, as in the case of the DEMATEL and WINGS methods we can use an ordinary spreadsheet. The problems with the liminal form of the super-matrix in the ANP method require that specialist software be used to perform the calculations. Ultimately, the authors chose the WINGS method (which is an extension of the classic DEMATEL method) in order to solve the problem in question. As mentioned, the tool used in the modelling of the dependencies between the elements of the system is the directed graph of direct influence, in which the graph's vertices represent 
the elements of the system and the arches determine the direction and intensity of the influence of elements on each other, similarly as in the DEMATEL method. However, the advantage of the WINGS method over the classic DEMATEL method is that it also accounts for-apart from the aforementioned intensity of influence-element significance, as the final effect of the influence between the system's elements is defined by a combination of both of these factors, instead of the intensity of influence alone, which is the case with the DEMATEL method [8]. Because of this, additional weights which describe the significance of the elements within the system were defined on the vertices of the aforementioned direct influence graph in the WINGS method.

Considering the aforementioned advantages of the WINGS method, the authors propose a network-based structure of the decision model as part of the extension of this method, which accounts for the importance of criteria $\left\{C_{1}, C_{2}, C_{3}, \ldots C_{n}\right\}$, interdependence between criteria and feedback in relations between criteria and decision alternatives $\left\{V_{1}, V_{2}, V_{3}, \ldots V_{n}\right\}$. Additionally, all relationships, in addition to their influence, also have a positive or negative nature (Figure 2).

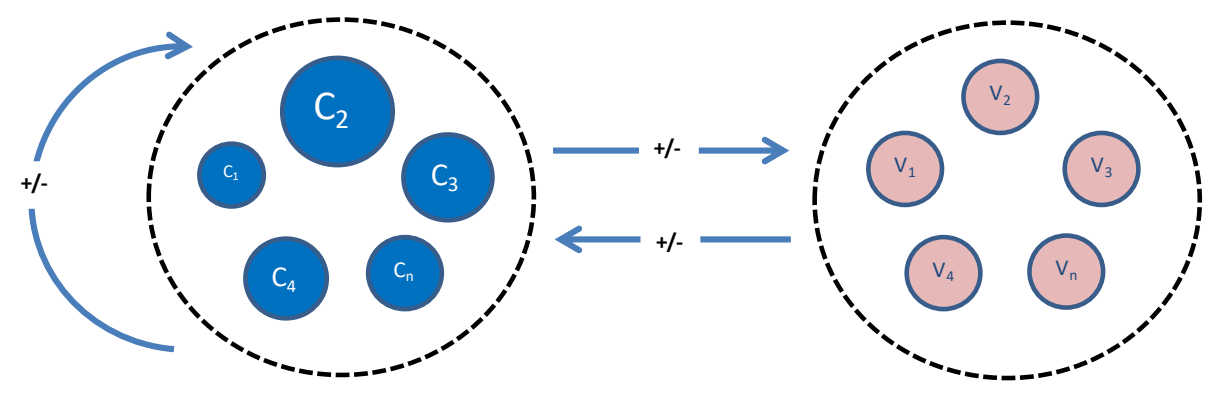

Figure 2. Schematic diagram of the proposed interactions between elements in the network structure of the decision model of the choice of a form of use alternative in the adaptation of a historic building.

The parameterisation of the network structure of the model will be based on collecting the opinions of experts and standardising them so that they take on numerical values determining criteria significance and the intensity and direction of the influence between the criteria and decision alternatives. Due to the imprecise and incomplete nature of the information that the experts must work with during the initial phase of the decision-making process, the authors proposed the use of the fuzzy logic to model the uncertainty of the experts' opinions.

Additionally, the interdisciplinary character of the analysed problem and the subjective, preference-dependant and often divergent character of the opinions of experts requires the introduction of group evaluation followed by its aggregation.

\subsection{New Extension of the Fuzzy Weighted Influence Non-Linear Gauge System (WINGS) Method Algorithm}

The stages of the calculation procedure of the WINGS method in its version modified by the authors in relation to the fuzzy extension of this method that was proposed earlier by Radziszewska-Zielina, Śladowski in [29] have been presented below. The modification introduced by the authors applies to utilising a more precise method of aggregating expert opinions.

Stage 1: The elements of the network structure of the model are defined by determining the elements of the system under analysis (criteria and decision alternatives).

For this purpose, it was decided to use the knowledge of experts with engineering, sociological, economic and heritage conservation experience in the field of historic buildings. Determining the expert population is very difficult because of to the specificity of the problem of adapting historic buildings, which is why it was decided to purposefully choose a research sample. The targeted selection of experts was made arbitrarily based on knowledge of the studied topic and belief in the representativeness of the sample [36]. Based on face-to-face interviews with five experts, questionnaires were filled out and the structure of the system was determined (criteria and decision variants and their dependencies). 
Stage 2: Experts perform an evaluation of the significance (weight) of each criterion and define inter-element influence direction within the system, as well as the character of the influence (positive or negative). For this purpose, experts use a linguistic rating scale presented in Table 1, with the ratings represented by triangular fuzzy numbers [37] as presented in Figure 3.

Table 1. Linguistic assessment of element significance and influence and their representation as triangular fuzzy sets, based on [29].

\begin{tabular}{|c|c|c|c|}
\hline \multicolumn{2}{|c|}{ Assessing Element Significance in the System } & \multicolumn{2}{|c|}{ Assessing Element Influence in the System } \\
\hline Linguistic assessment & Triangular fuzzy numbers & Linguistic assessment & Triangular fuzzy numbers \\
\hline No significance (NS) & $(0,0,1)$ & No influence (NI) & $(0,0,1)$ \\
\hline Low significance (LS) & $(0,1,2)$ & Low influence (LI) & $(0,1,2)$ \\
\hline Average significance (AS) & $(1,2,3)$ & Average influence (AI) & $(1,2,3)$ \\
\hline High significance (HS) & $(2,3,3)$ & High influence (HI) & $(2,3,3)$ \\
\hline
\end{tabular}

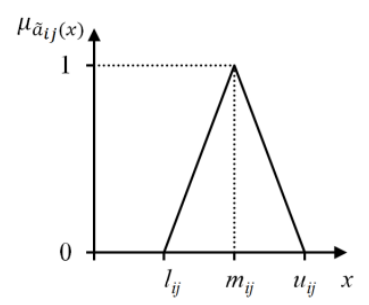

$$
\mu_{\tilde{a}_{i j}}(x)= \begin{cases}0, & x<l_{i j} \\ \left(x-l_{i j}\right) /\left(m_{i j}-l_{i j}\right), & l_{i j} \leq x \leq m_{i j} \\ \left(u_{i j}-x\right) /\left(u_{i j}-m_{i j}\right), & m_{i j} \leq x \leq u_{i j} \\ 0, & x>u_{i j}\end{cases}
$$

Figure 3. A representation of a linguistic opinion of an expert in the form of a triangular fuzzy set [29].

The linguistic assessment scale makes it possible to express opinions about phenomena that are difficult to measure in a natural manner, often in conditions of incomplete, imprecise and uncertain information [38]. The triangular shape of the membership function for the fuzzy number as the representation of the linguistic assessment scale is a basic shape used in fuzzy decision-making models [39]. Changes in membership between this function's parameters take on the form of a linear interpolation, which corresponds to the intuitiveness of expert opinions [29]. Triangular fuzzy numbers are also easily implemented in basic arithmetical operations used in the proposed method. The aforementioned assessment scale uses four categories described by triangular fuzzy numbers, which define the space of possible ratings (Figure 4). This scale is based on the proposition presented in [40]. Before formulating their opinions, experts should familiarise themselves with the assessment scale and accept it.

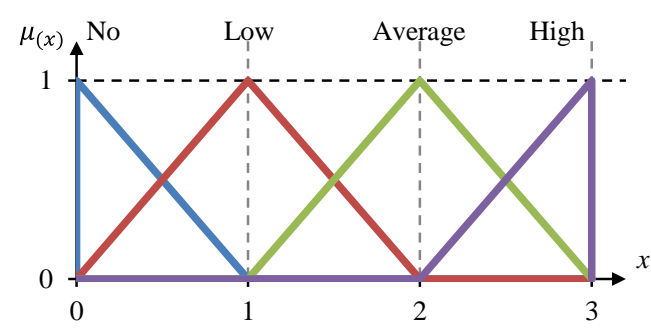

Figure 4. Spaces for linguistic variables illustrating the significance/influence of a system element, based on [29].

The advantage of using triangular fuzzy numbers is the simple implementation of arithmetical operations used in the proposed method. Arithmetical operations on any two triangular fuzzy numbers $\widetilde{a}_{11}=\left(l_{11}, m_{11}, u_{11}\right)$ and $\widetilde{a}_{12}=\left(l_{12}, m_{12}, u_{12}\right)$ are thus as follows [29]:

$$
\widetilde{a}_{11} \oplus \widetilde{a}_{12}=\left(l_{11}+l_{12}, m_{11}+m_{12}, u_{11}+u_{12}\right)
$$




$$
\begin{gathered}
\widetilde{a}_{11} \ominus \widetilde{a}_{12}=\left(l_{11}-u_{12}, m_{11}-m_{12}, u_{11}-l_{12}\right) \\
\widetilde{a}_{11} \otimes \widetilde{a}_{12}=\left(l_{11} l_{12}, m_{11} m_{12}, u_{11} u_{12}\right) \\
\widetilde{a}_{11} \otimes \widetilde{a}_{12}=\left(l_{11} l_{12}, m_{11} m_{12}, u_{11} u_{12}\right)
\end{gathered}
$$

Stage 3: Decomposition of the model structure into two subnetworks-one for positive relationships between system components and the other for negative relationships. The following steps are performed for each subnetwork.

Stage 4: Expert opinions are the basis for defining a set of fragmentary matrices $\widetilde{D}_{k}=\left\{\widetilde{a}_{i j k}\right\}$, $i, j=1, \ldots, n, k=1,2, \ldots, K$, of direct significance influence, for which $\widetilde{a}_{i j k}=\left(l_{i j k}, m_{i j k}, u_{i j k}\right)$ are fuzzy numbers with a triangular membership function $\mu_{\widetilde{a}_{i j k}}(x) \in[0,1]$ expressing the fuzzy assessment of the relationship between element $i$ and $j$ expressed by expert $k=1,2, \ldots, l[29]$.

$$
\widetilde{D}_{k}=\left[\begin{array}{cccc}
\widetilde{a}_{11 k} & \widetilde{a}_{12 k} & \ldots & \widetilde{a}_{1 n k} \\
\widetilde{a}_{21 k} & \widetilde{a}_{22 k} & & \widetilde{a}_{2 n k} \\
& \vdots & \ddots & \vdots \\
\widetilde{a}_{n 1 k} & \widetilde{a}_{n 2 k} & \cdots & \widetilde{a}_{n n k}
\end{array}\right]
$$

The main diagonal of matrix $\widetilde{D}_{k}$ will contain elements $\widetilde{a}_{i j k}, i, j=1, \ldots, n, i=j$, that define the significance (weight) of an element (a given decision criterion) within the system, while elements $\widetilde{a}_{i j k}, i, j=1, \ldots, n, i \neq j$, define the relationships and their intensity between system elements (criteria and decision variants).

Stage 5: Standardisation of the direct significance-influence matrix $\widetilde{D}_{k}$ should be performed using the formula below [29]:

$$
\widetilde{C}_{k}=\frac{1}{s_{k}} \otimes \widetilde{D}_{k}
$$

where the standardising factor $s_{k}$ should be determined in accordance with the formula below:

$$
s_{k}=\sum_{i=1}^{n} \sum_{j=1}^{n} u_{i j k}
$$

As a result, every element of the standardised direct significance-influence matrix $\widetilde{C}_{k}$ will take on the form of a three-dimensional vector:

$$
\widetilde{c}_{i j k}=\left(\frac{l_{i j k}}{s_{k}}, \frac{m_{i j k}}{s_{k}}, \frac{u_{i j k}}{s_{k}}\right)
$$

Stage 6: The direct significance-influence matrix $\widetilde{C}_{k}$ will be used to determine the resultant total significance-influence matrix (containing the direct and indirect relationships between the system's elements) $\widetilde{T}_{k}=\left\{\widetilde{t}_{i j k}\right\}$ for which $\widetilde{t}_{i j k}=\left(l_{i j k}, m_{i j k}, u_{i j k}\right)$, which is defined as follows [29]:

$$
\widetilde{T}_{k}=\widetilde{C}_{k} \oplus \widetilde{\Delta T}_{k}
$$

for which $\widetilde{\Delta T}_{k}=\widetilde{C}_{k}^{2} \oplus \widetilde{C}_{k}^{3} \oplus \ldots \widetilde{C}_{k}^{p}$ is the matrix of indirect significance-influence, which is the sum of the successive exponents of direct significance-influence matrices $\widetilde{C}_{k}$.

Because $\lim _{p \rightarrow \infty} \widetilde{C}_{k}^{p}=[0]_{n x n}$, ultimately, the matrix of total significance-influence can be calculated via using the dependency below:

$$
\widetilde{T}_{k}=\sum_{p=1}^{\infty} \widetilde{C}_{k}^{p}=\widetilde{C}_{k}\left(\mathrm{I} \ominus \widetilde{C}_{k}\right)^{-1}
$$


for which: I is a unit matrix.

Stage 7: The total significance-influence matrix $\widetilde{T}_{k}=\left\{\widetilde{t}_{i j k}\right\}$ that has been calculated constitutes a basis for obtaining the final results through determining the values of total influence $r_{i k}$ of system element $i$, as well as of its total susceptibility $c_{i k}$ based on the following dependencies:

$$
\begin{aligned}
& \widetilde{r}_{i k}=\sum_{j=1}^{n} \widetilde{t}_{i j k} \\
& \widetilde{c}_{i k}=\sum_{j=1}^{n} \widetilde{t}_{j i k}
\end{aligned}
$$

Stage 8: A group of $\mathrm{k}$ experts assesses the significance and influence of system elements, which results in a k-number of total influence $r$ and total susceptibility $c$ vectors with triangular fuzzy numbers described by $\mu_{\widetilde{r_{i k}}}(x) \in[0,1]$ and $\mu_{\widetilde{c_{i k}}}(x) \in[0,1]$ membership functions. To aggregate the assessments of all experts we should determine the averaged and standardised membership functions reflecting the total influence and total susceptibility of each of the elements according to the formulae below [41]:

$$
\begin{aligned}
& \mu_{\widetilde{r_{i}}}(x)=\frac{1}{K} \sum_{k=1}^{K} \mu_{\widetilde{r}_{i k}}(x) \\
& \mu_{\widetilde{c_{i}}}(x)=\frac{1}{K} \sum_{k=1}^{K} \mu_{\widetilde{c_{i k}}}(x)
\end{aligned}
$$

Stage 9: During this step, a defuzzification of the vectors obtained through aggregation needs to be performed. It can be done using several methods, including the COG (center of gravity) defuzzification method [42,43], which the authors employed in their approach.

$$
\begin{aligned}
r_{i} & =\frac{\int_{a}^{b} \mu_{\widetilde{r_{i}}}(x) \cdot x d x}{\int_{a}^{b} \mu_{\widetilde{r_{i}}}(x) d x} \\
c_{i} & =\frac{\int_{a}^{b} \mu_{\widetilde{c_{i}}}(x) \cdot x d x}{\int_{a}^{b} \mu_{\widetilde{c_{i}}}(x) d x}
\end{aligned}
$$

where: $r_{i}$ and $c_{i}$ are defuzzified values of an element of aggregated vectors $r$ and $c$, while $\mu_{\widetilde{r}_{i}}$ and $\mu_{c_{i}}$ are the values of the membership function of a fuzzy element of aggregated vectors $r$ and $c$.

The value of $r_{i}+c_{i}$ is called the total engagement of system element $i$, while $r_{i}-c_{i}$ defines its role within the system. Positive results from this equation inform us that element $i$ is a cause within the system, while a negative value indicates that it is an effect. The strength of the aforementioned causal (effectual) character of the element is indicated by the absolute value of the result of difference $r_{i}-c_{i}$. The values obtained in this manner can be graphically represented in a two-dimensional coordinate system creating an impact-relations map (IRM). The values of the difference $r_{i}-c_{i}$ are placed on the ordinate, while the values of the sum $r_{i}+c_{i}$ on the abscissa [29].

Stage 10. The following formulas will be used for the synthesis of results:

additive synthesis (negative) $w_{\text {pos }}\left(r_{i \text { pos }}+c_{i \text { pos }}\right)-w_{\text {neg }}\left(r_{i \text { neg }}+c_{i \text { neg }}\right)$

additive synthesis (reciprocal) $w_{\text {pos }}\left(r_{i \text { pos }}+c_{i \text { pos }}\right)+w_{\text {neg }} \cdot 1 /\left(r_{i \text { neg }}+c_{i \text { neg }}\right)$

multiplicative synthesis (norm.) $\left(r_{i \text { pos }}+c_{i \text { pos }}\right) /\left(r_{i \text { neg }}+c_{i \text { neg }}\right)$

where: $w_{p o s}, w_{n e g}$ - the weightings of positive and negative relationships between system components determined in accordance with the decision-maker preferences. 


\section{Case Study}

Measurements necessary for multi-criteria analysis were carried out at a historic building located in the mountain tourist resort of Zakopane, Poland. In accordance with the principles of sustainable development, the measurements included both energy-efficiency tests, which report the consumption of energy resources, as well as measurements of the comfort of use of the building, a criterion that is very important from the user's point of view. Economic and social criteria were taken into account in the analysis. Such a wide spectrum of research is unique when this scientific problem is concerned. All of the tests that were performed for the purposes of the multi-criteria analysis are listed below.

\subsection{Criterion F1-Energy Efficiency}

Energy efficiency is an important goal for both new buildings and buildings under renovation [44,45] or historic buildings, as stipulated in Directive 2018/844 [46]. Numerous studies are carried out with the aim of determining which methods can be used to achieve the intended energy efficiency of a building [47-50].

Criterion F1-energy efficiency, consists of two sub-criteria.

Sub-criterion F1/P1-energy efficiency; improvement of the thermal quality of the building envelope.

In the first sub-criterion, depending on the adopted criterion, the possibility of improving the heat transfer coefficient of the building's envelope was analysed. The calculation method of the heat transfer coefficient for walls is included in the PN-EN ISO 6946 standard [51]. The calculations were performed based on the technical and construction-phase design of the Stara Polana building. The calculations account for the minimum requirements applicable in Poland, as stipulated in [52]. The calculated heat transfer coefficients for the walls, of course, does not fulfil the current requirements stipulated in [52]. The analysis assumed an improvement of thermal insulation of the envelope to the values required by applicable standards.

The second energy efficiency sub-criterion F1/P2 concerns the final energy indicator FE (Final Energy). This sub-criterion is related to the total energy consumption of the building to ensure an adequate level of comfort for users. Energy is used for the purposes of heating, cooling, ventilation and the operation of auxiliary equipment. The methodology for calculating final energy is contained in [53] and takes into account the total energy balance of the building.

\subsection{Criterion F2-Quality of the Building Envelope}

Sub-criterion F2/P1—quality of the building envelope; improving the tightness of the building envelope; detection of thermal bridges through thermography tests

The criterion regarding the quality of construction works is based on an analysis of the tightness of the building envelope using infrared methods to detect heat loss. Polish regulations do not impose the need for a leak test. The Ordinance of the Minister of Infrastructure concerning the technical conditions to be met by buildings and their placement [52] is the only document with a suggestion as to which air-tightness (heat leakage) the building envelope should have. For gravitational ventilation, the n50 leakage rate should be no higher than 3.0 air exchanges per hour. For further analysis, an "in situ" measurement of the actual leakage rate of the analysed building was carried out. The leak test was carried out based on the methodology outlined in the PN EN 13829 standard [54]. The test was performed on 8/05/2018, using the Retrotec Q5E device (with a capacity of $14100 \mathrm{~m} 3$ / h). Figure 5 shows how the leak test was performed in the "Stara Polana" building.

The building envelope leak test was supplemented with thermal vision tests in accordance with the method stipulated in the standard [55]. The "in situ" test was carried out using a FLIR E-75 thermal imaging camera with a thermal sensitivity of $0.06^{\circ} \mathrm{C}$ and a bolometric matrix resolution of $320 \times 240$. One of the thermal images taken during the tests is shown in Figure 6. 


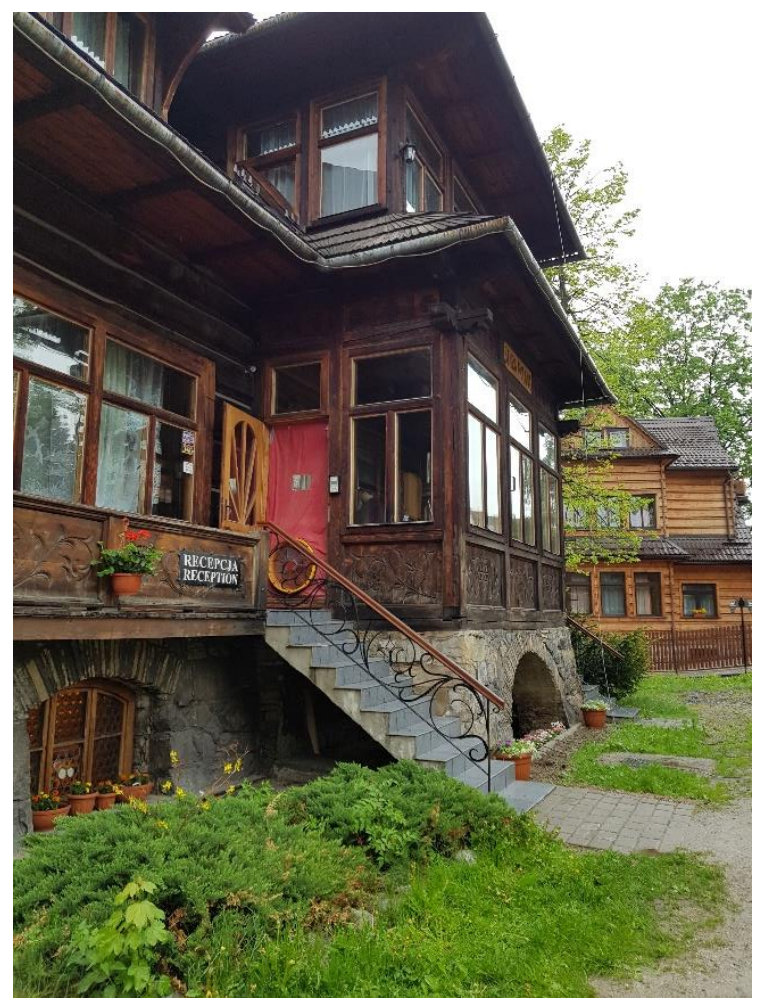

Figure 5. Leak test at the 'Stara Polana' hostel [30].
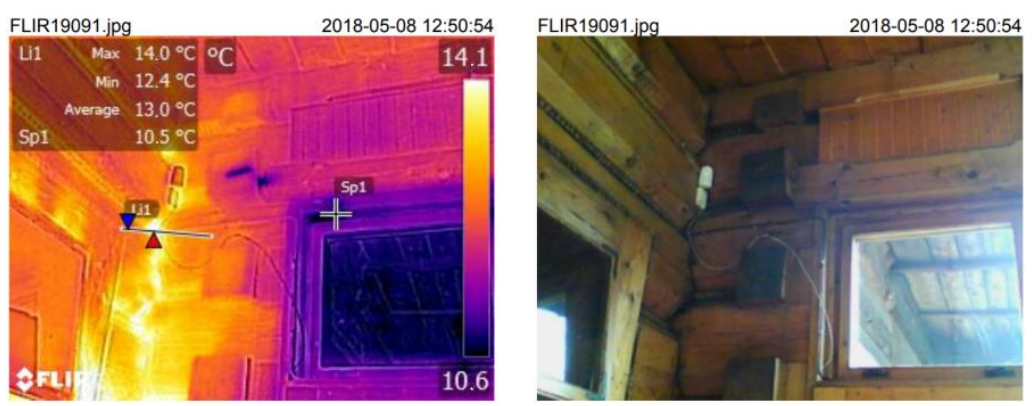

Figure 6. Leak detection in the building envelope using a thermal imaging camera [30].

\subsection{Criterion F3-Internal Comfort of Use}

\subsubsection{Subcriterion F3/P1—Room Comfort; Thermal Comfort}

The criterion of ensuring the comfort of NZEB (nearly zero energy buildings) is one of the priorities, alongside ensuring the minimisation of energy consumption in low-energy buildings [56,57]. In this type of building with large windows, in particular, ensuring thermal comfort requires conscious design. The issue of ensuring thermal comfort has been the subject of many studies described in [58-60]. Thermal comfort tests were carried out based on the methodology stipulated in the PN-EN ISO 7730 (Fanger methodology) [61] and PN ISO 7726 [62] standards. In accordance with PN-EN ISO 7730 [61], the categories of thermal comfort of rooms are determined on the basis of the PMV (predicted mean vote) thermal comfort coefficient achieved. In situ tests were performed using a microclimate meter (Figure 7). The research was carried out from 22/05/2018 to 31/05/2018. Parameters for measurements were adopted based on the PN-EN ISO 9920: 2009 [63] standard. The parameters measured were: air temperature, relative humidity, air flow speed, infrared radiation. Data were collected with a frequency of $5 \mathrm{~min}$. 


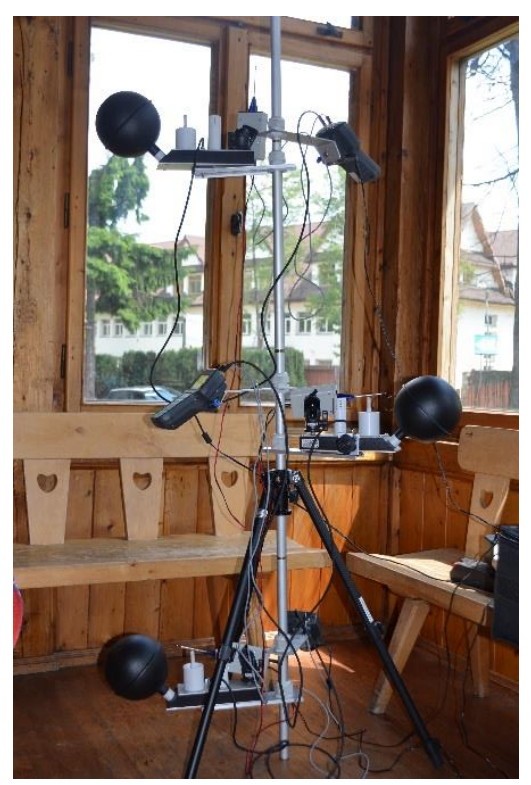

Figure 7. Test device for measuring thermal comfort [30].

\subsubsection{Subcriterion F3/P2-Room Comfort; Vibration Comfort}

Vibroacoustic comfort is another aspect of comfort that has been explored in the paper. This is a very important aspect of the comfort of buildings, discussed by numerous authors [64-66]. The building under analysis is located in a vibration source zone-a through street with heavy traffic. The building is in a dynamic influence zone [67]. In situ measurements were made on 8/5/2018. The testing devices used were accelerometers, with parameters consistent with $[57,68]$. The measuring points were located in the ground-floor lobby and in a first-floor guest room. Piezoelectronic accelerometers were placed in the middle of the floor, as outlined in [69] and vibrations were measured in three perpendicular directions: two horizontal and one vertical direction. The accelerometers were placed on a special disc which simulates the weight of a human body in accordance with [69] (Figure 8).

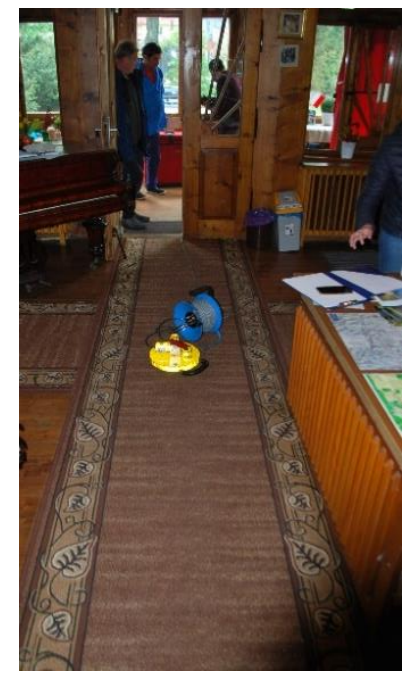

Figure 8. Measurement discs located in the hall of "Stara Polana" [30].

Vibration test results were used for human perception assessment via the RMS (Root Mean Square) procedure outlined in $[69,70]$. 


\subsubsection{Criterion F3/P3-Room Comfort; Acoustic Comfort}

Acoustic comfort is associated with vibroacoustic comfort. The measurement methodology used in this study has been described in [71-78] and based on European [78] and Polish standards [79]. The measurements were carried out on 8/5/2018 at 12:00 and 18:30. The tests were carried out for three zones in 28 rooms. The first zone, with the outer wall from the side of a busy street, the second zone inside the building and the third zone in the newest part of the building at the back, away from the street. The location of the control point is shown in Figure 9. In "in situ" tests, there were three sound level positions, at least $1 \mathrm{~m}$ away from interior walls and $1.5 \mathrm{~m}$ away from external walls with windows. The height of the microphone was $1.2 \pm 0.1 \mathrm{~m}$. The noise level measurements for each position took $4 \mathrm{~min}$; the total measurement time for each room was $12 \mathrm{~min}$. Apart from room noise levels, daytime and night-time street noise levels were measured as well.

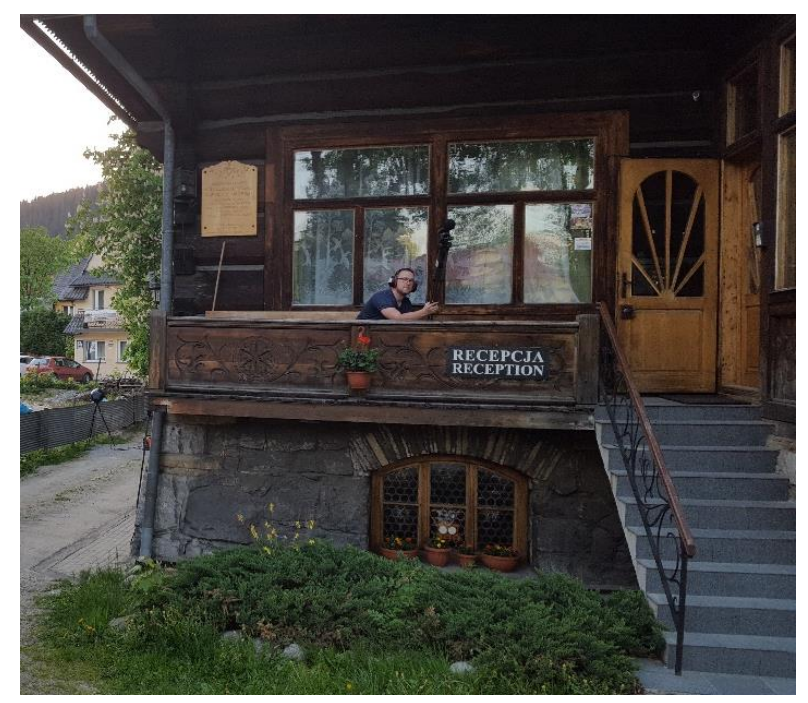

Figure 9. Location of measurement point in front of the building ( $2 \mathrm{~m}$ from the façade and $4 \mathrm{~m}$ above the ground) [30].

\subsection{Criterion F4-Impact on the Environment}

Subcriterion F4/P1-Impact on the Environment; PE (Primary Energy) Coefficient $\left(\mathrm{kWh} /\left(\mathrm{m}^{2} \mathrm{y}\right)\right.$ )

The criterion of the building's impact on the environment was determined by the non-renewable primary energy (PE) indicator $\left(\mathrm{kWh} /\left(\mathrm{m}^{2} \mathrm{a}\right)\right)$. The PE indicator largely depends on the energy sources used. The indicator is more favourable for buildings powered by renewable energy sources and determines the building's environmental impact. Concerning calculation methodology, the PE calculations for the "Stara Polana" building were performed as stipulated in [53].

\subsection{Financial Criterion F5}

The financial criterion was based on the profitability index (PI) method described in [80]. Based on this method, it was determined whether the project was financially effective and, therefore, whether the developer's financial gains from the building in a given period of time will be greater than the expenses incurred [81]. The higher the index value, the more profitable the new alternative. If the value for the given form of use is greater than 1 (PI $>1$ ), the building adaptation is profitable for this alternative. The profitability indices have been obtained assuming 15 -year period.

\subsection{Criteria F6-Societal Benefits, and F7-Benefits from Preserving Cultural Heritage}

The last criteria adopted for the analysis are: F6-Societal Benefits and F7-Benefits from Preserving Cultural Heritage. Both are associated with a sense of identity and national (cultural) 
integration. The criteria express the emotional ties of society with a historical structure, which is a testimony of historical eras, and the acceptance of the use of historic buildings for social purposes by society [82-84]. The assessment of each of the building's adaptation alternatives was determined individually for each criterion. The factor significance assessment of a given criterion entailed the collection of opinions expressed by a small group of specialists in the field of each criterion. The expert assessment returned a group rating that allowed differences in the preferences that these opinions showed to be accounted for. Structural modelling was used in the analysis, with a set of different techniques applied to understand the properties of complex systems and decision problems [32].

\section{Results}

A range of tests and studies from different disciplines was used to determine the potential of the form of use alternatives under study, thereby defining rating values from the perspective of each criterion. A summary of the criteria and subcriteria for each variant has been presented in Table 2.

Table 2. Summary table [30].

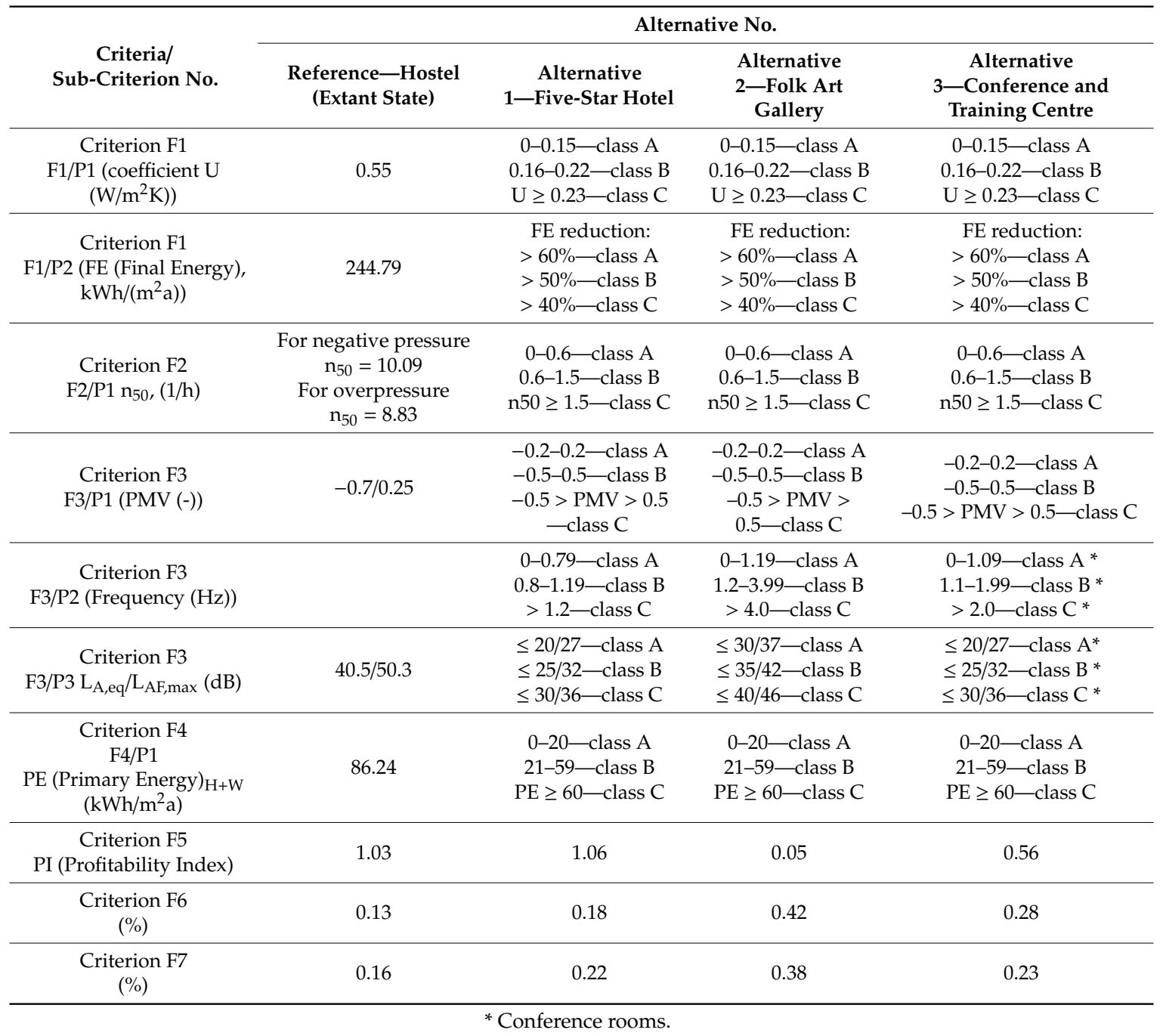

Figures 10-12 present the relationships, that occur between the analysed criteria and decision alternatives, as per the assessment of the first expert. Green arrows indicate positive impact and red arrows negative. The thickness of the arrow determines impact intensity, while the size of the nodes representing the criteria corresponds to the importance of these criteria. In the case of alternatives, no weights were determined, hence the same node size. Figure 10 shows both positive and negative 
influences. Figures 11 and 12 present the positive and negative influences separately, while Figure 13 presents the significance of individual criteria according to expert assessment.

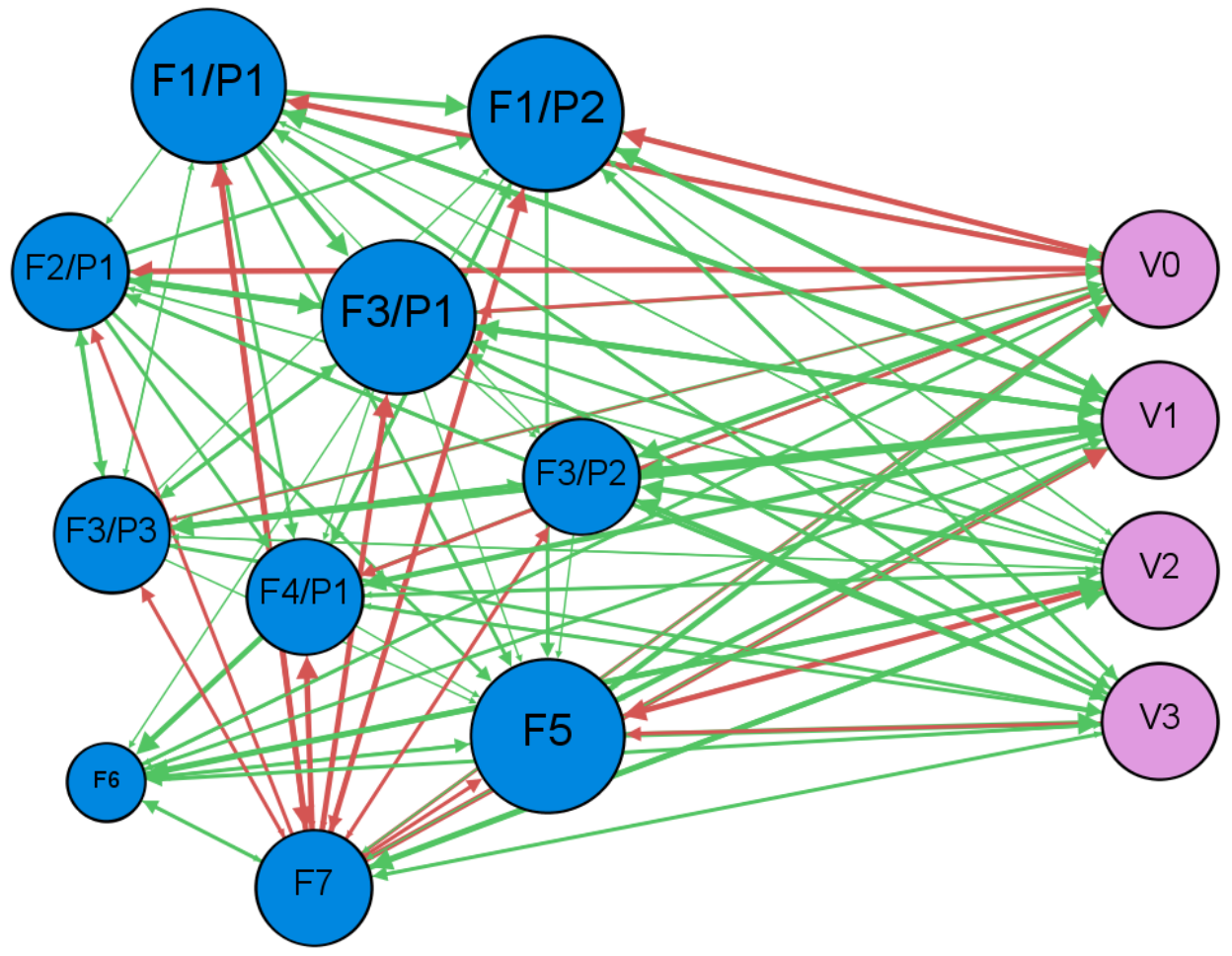

Figure 10. Positive and negative relations that occur between the analysed criteria and decision alternatives according to the assessment of the first expert.

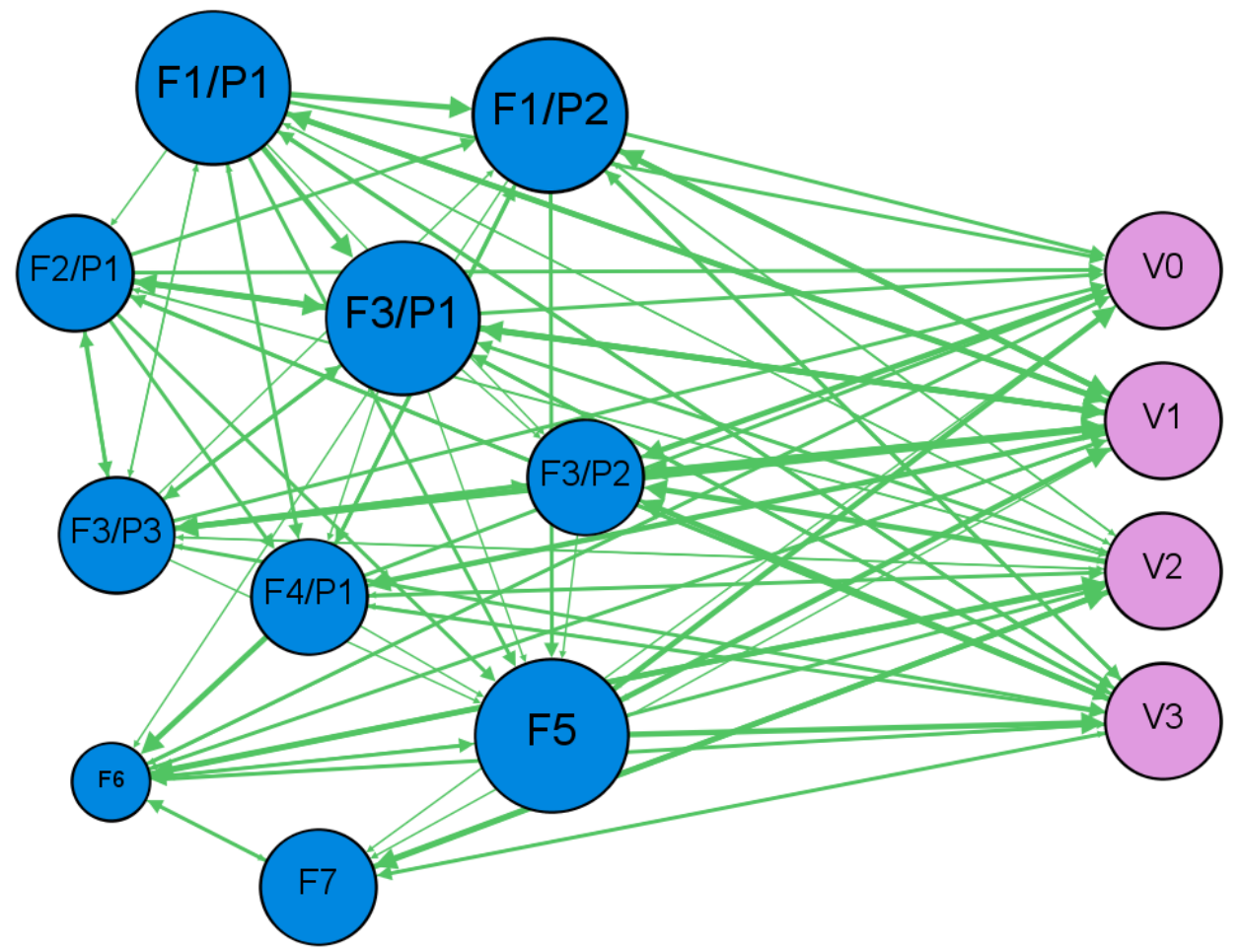

Figure 11. Positive relations that occur between the analysed criteria and decision alternatives according to the first expert's assessment. 


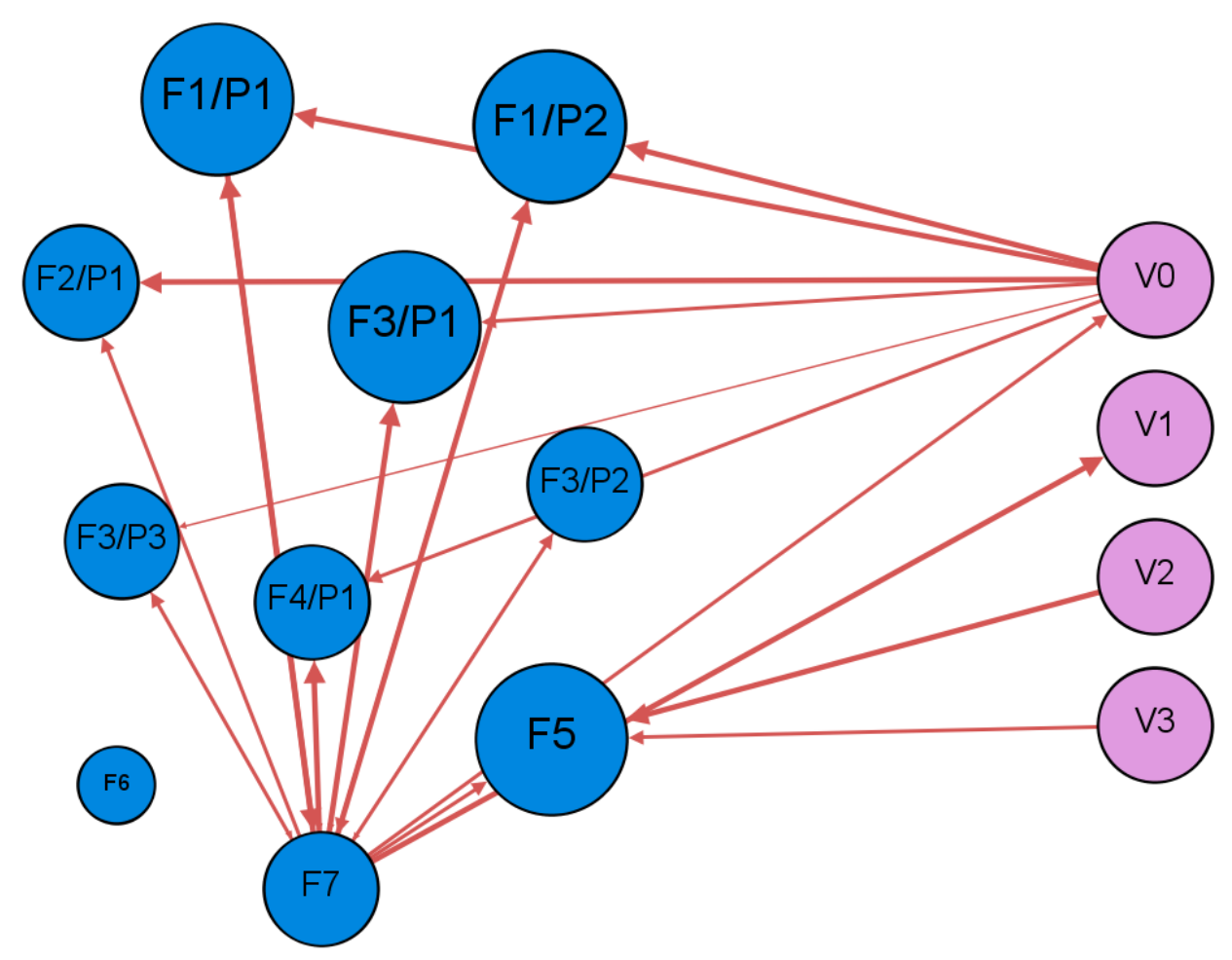

Figure 12. Negative relations that occur between the analysed criteria and decision alternatives according to the assessment of the first expert.

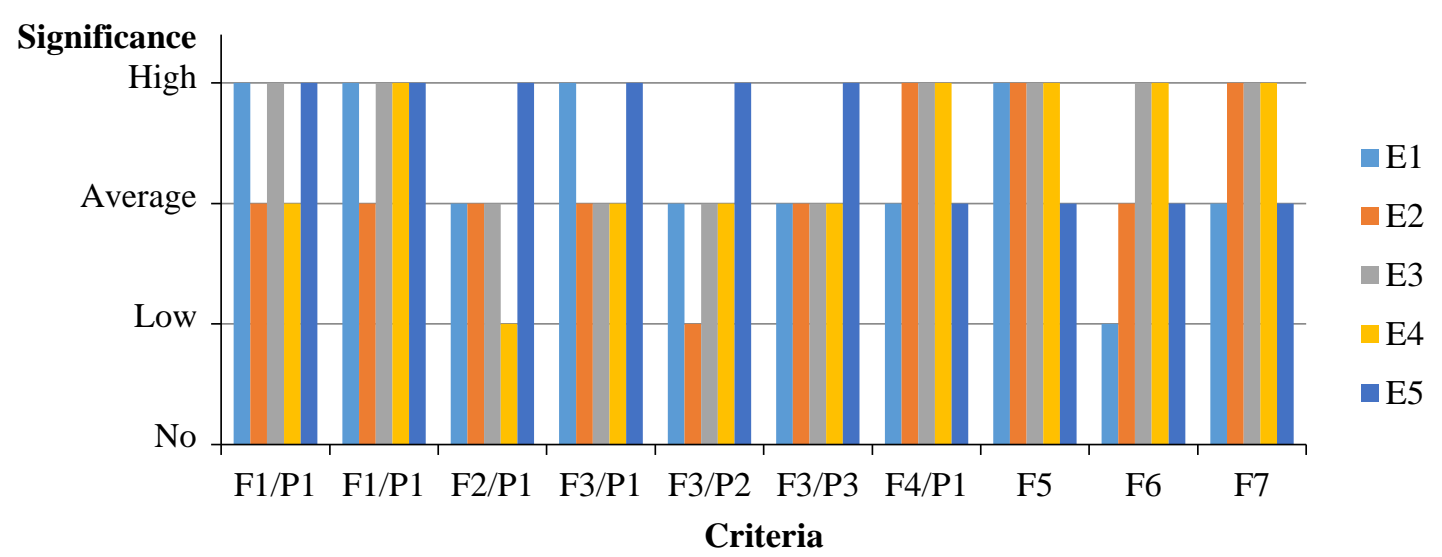

Figure 13. Significance of individual criteria according to expert assessment (E1, E2, ... ,E5 - experts).

As a result of processing the input data, the influences and susceptibilities of individual alternatives have been determined in both positive and negative relationships. Their fuzzy form is shown in Figures 14-17. 


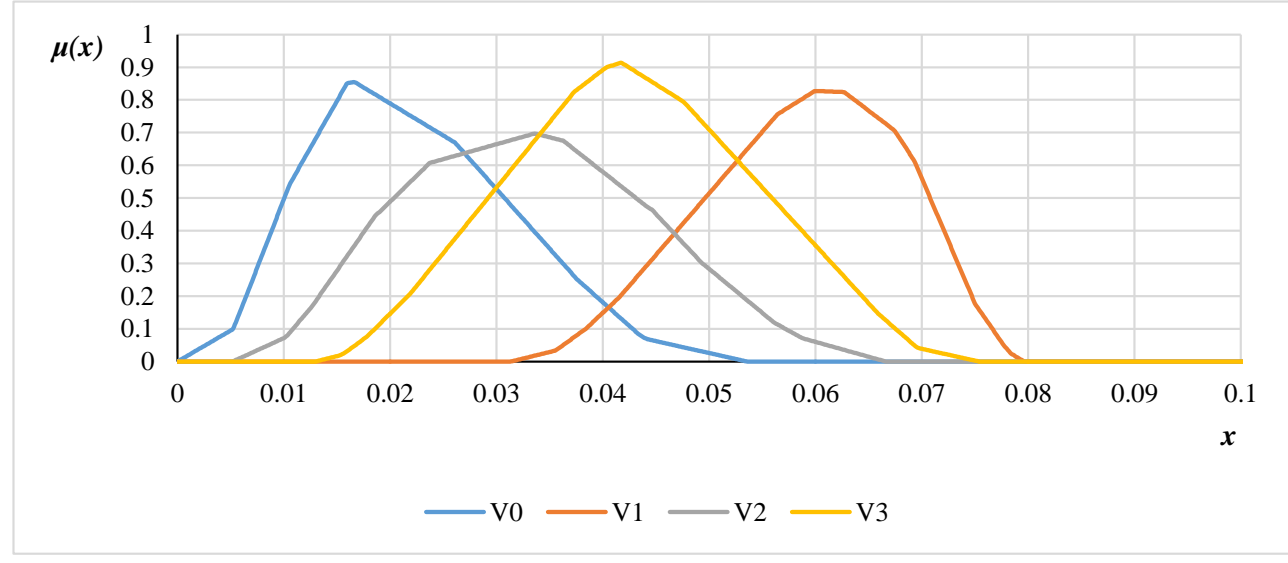

Figure 14. Total influence $r$ of alternatives when analysing positive relationships.

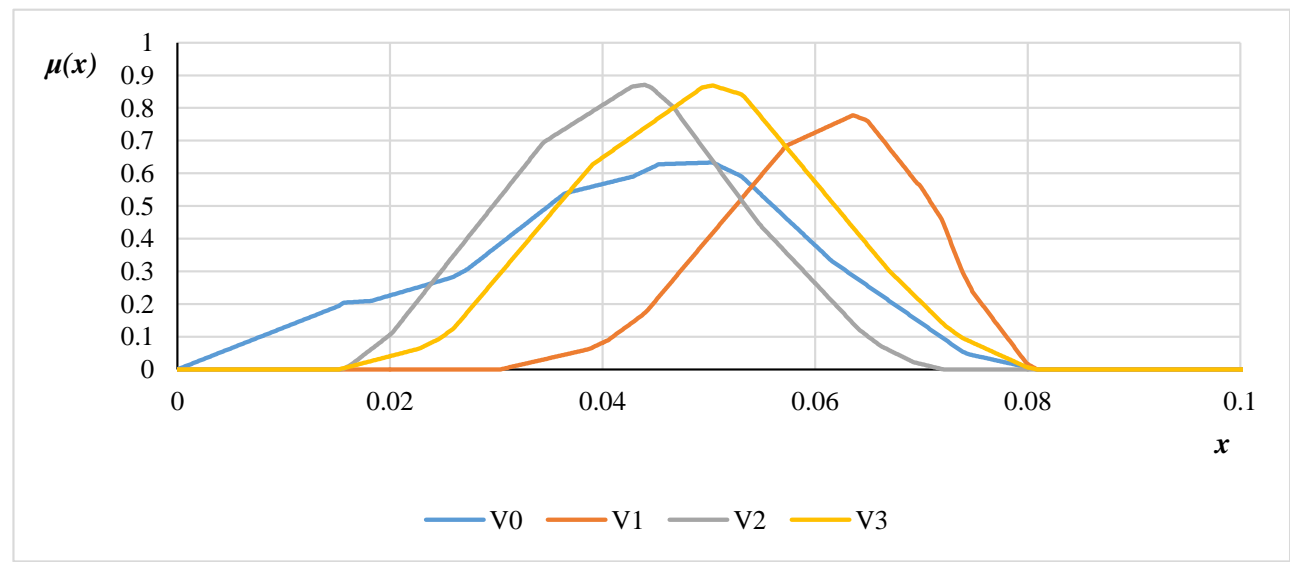

Figure 15. Total susceptibility $c$ of alternatives when analysing positive relationships.

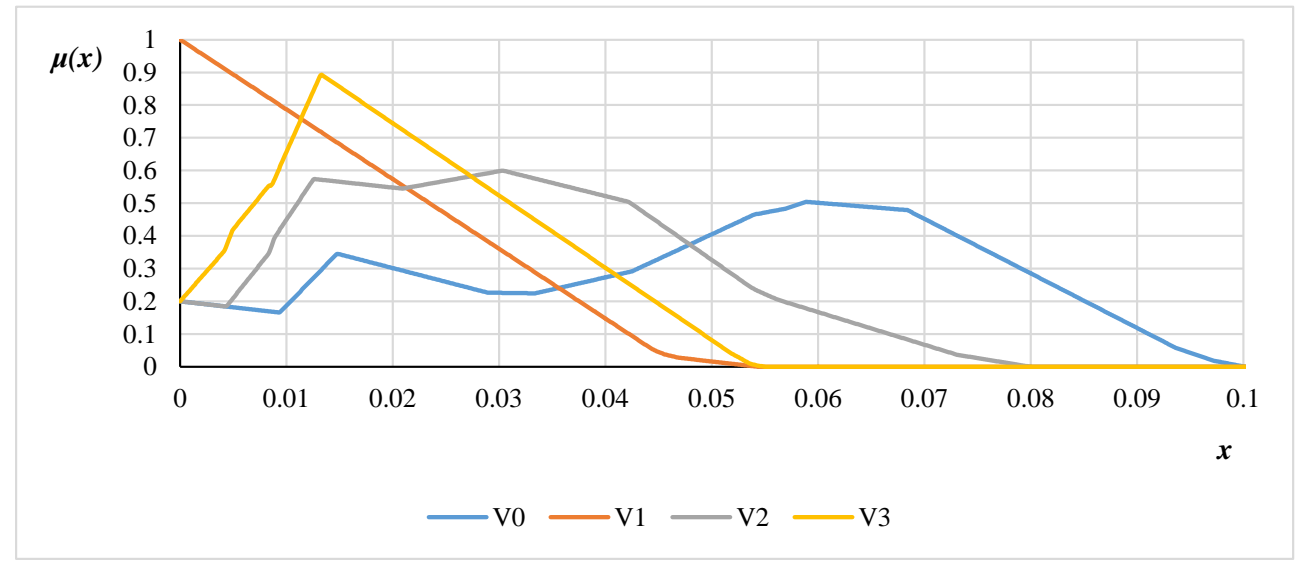

Figure 16. Total influence $r$ of alternatives when analysing negative relationships. 


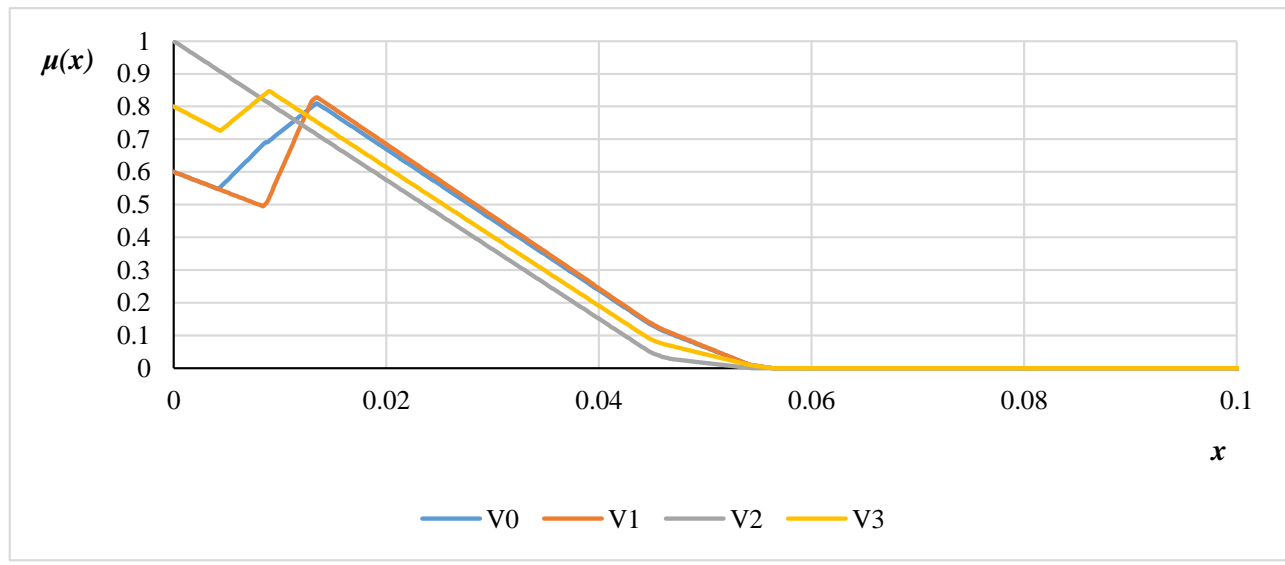

Figure 17. Total susceptibility of c alternatives when analysing negative relationships.

The crisp values of influences, susceptibilities, as well as engagement and role related to the options considered are summarised in Table 3.

Table 3. Crisp values of total influence $r$, susceptibility $c$, engagement $r+c$ and the role $r-c$ for the analysed alternatives and the nature of the relationship.

\begin{tabular}{lcccccccc}
\hline Alternatives & Positive Relationships & \multicolumn{5}{c}{ Negative Relationships } \\
\hline & $r$ & $c$ & $r+c$ & $r-c$ & $r$ & $c$ & $r+c$ & $r-c$ \\
V0 & 0.022 & 0.042 & 0.065 & -0.020 & 0.049 & 0.019 & 0.069 & 0.030 \\
V1 & 0.059 & 0.060 & 0.119 & -0.001 & 0.016 & 0.020 & 0.036 & -0.004 \\
V2 & 0.033 & 0.042 & 0.075 & -0.009 & 0.031 & 0.016 & 0.047 & 0.015 \\
V3 & 0.043 & 0.049 & 0.092 & -0.006 & 0.022 & 0.017 & 0.039 & 0.004 \\
\hline
\end{tabular}

The results showing the final assessments of individual decision options made on the basis of the total engagement $r+c$ values in the system are presented in Table 4 . They concern the consideration of positive and negative relationships (columns $3,4,5$ ) and the use of different synthesis formulas to aggregate positive and negative relationships (columns 6, 7, 8).

Table 4. Synthesis of results related to final assessments of the analysed alternatives.

\begin{tabular}{cccccccc}
\hline Alternatives & Rating & $\begin{array}{c}\text { Positive } \\
\text { Relations } \\
\text { (norm.) }\end{array}$ & $\begin{array}{c}\text { Negative } \\
\text { Relations } \\
\text { (norm.) }\end{array}$ & $\begin{array}{c}\text { Inverted } \\
\text { Negative } \\
\text { Relations } \\
\text { (norm.) }\end{array}$ & $\begin{array}{c}\text { Additive } \\
\text { Synthesis } \\
\text { (Negative) } \\
\text { (norm.) }\end{array}$ & $\begin{array}{c}\text { Additive } \\
\text { Synthesis } \\
\text { (Reciprocal) }\end{array}$ & $\begin{array}{c}\text { Multiplicative } \\
\text { Synthesis } \\
\text { (norm.) }\end{array}$ \\
\hline V0 hostel & 4 & 0.184 & 0.360 & 0.163 & -0.424 & 0.174 & 0.115 \\
$\begin{array}{l}\text { V1 hotel } \\
\text { V2 art }\end{array}$ & 1 & 0.339 & 0.188 & 0.313 & 0.366 & 0.326 & 0.405 \\
$\begin{array}{c}\text { gallery } \\
\quad \text { V3 }\end{array}$ & 3 & 0.215 & 0.246 & 0.239 & -0.076 & 0.227 & 0.195 \\
$\begin{array}{c}\text { Conference } \\
\text { centre }\end{array}$ & 2 & 0.262 & 0.206 & 0.285 & 0.134 & 0.273 & 0.285 \\
\hline
\end{tabular}

Variant ratings, performed on the basis of final assessments of positive and negative impacts, as well as various formulas for the synthesis of results is unchanging and indicates alternative 1 (hotel) as the one that best meets the adopted decision criteria. It has the greatest benefits within the adopted set of criteria and minimises the negative impact on these criteria. It can also be pointed out that the current form of use of the building under analysis was rated the worst among the considered options 


\section{Discussion}

Poor assessment of the existing form of use of the buildings indicates the desirability of undertaking restoration measures aimed at improving the technical condition of the facility, its functional and utilitarian solutions, comfort of use and economic efficiency while maintaining cultural heritage and accounting for the impact of the building on the natural environment and the local community.

The results of the analysis clearly show that option 1, a hotel, is the solution which is rated the best in light of the adopted criteria set. This is the most favourable option, both in terms of maximising benefits and minimising negative impact on the analysed criteria. Therefore, each of the three formulas used to synthesise the final results also indicates the hotel as the most advantageous solution.

The analysis displayed a clear predominance of positive interactions between elements of the system (119.2 positive interactions on average, compared to 17.6 negative interactions on average). Figure 18 presents the influence map for individual criteria, while Figure 19 presents the influence map for individual variants. On the map of positive relations, it can be observed that the largest engagement in the system $(r+c)$ is characterised by criteria related to the improvement of thermal conditions in the building (F1/P1-improvement of insulation of external envelope, F1/P2-improvement of the final energy indicator FE, F2/P1—quality of the building (tightness ), F3/P1—thermal comfort). This means that these criteria should be considered key criteria in the decision-making problem. Their improvement will also translate into lower heating energy consumption, environmental protection and lower operating costs. In the case of the considered alternatives, alternative V1-a hotel clearly stands out.

In the case of negative impacts, two criteria which differ from the others are clearly visible: F5-financial aspects (profitability index) and F7-aspects of cultural heritage protection. The first one is below the horizontal axis, so other elements of the system have a negative impact on this criterion that is greater than its own impact on other criteria. In the case of criterion F7, the opposite is true. Improving other criteria will often result in higher costs, while the wish to preserve cultural heritage will limit the solutions specific to commercial functions to the greatest degree. The base alternative on the map of negative relations is also separated from the others, which results from the fact that in its current form the building does not fulfil thermal requirements related to the comfort of use of the building and energy demand.

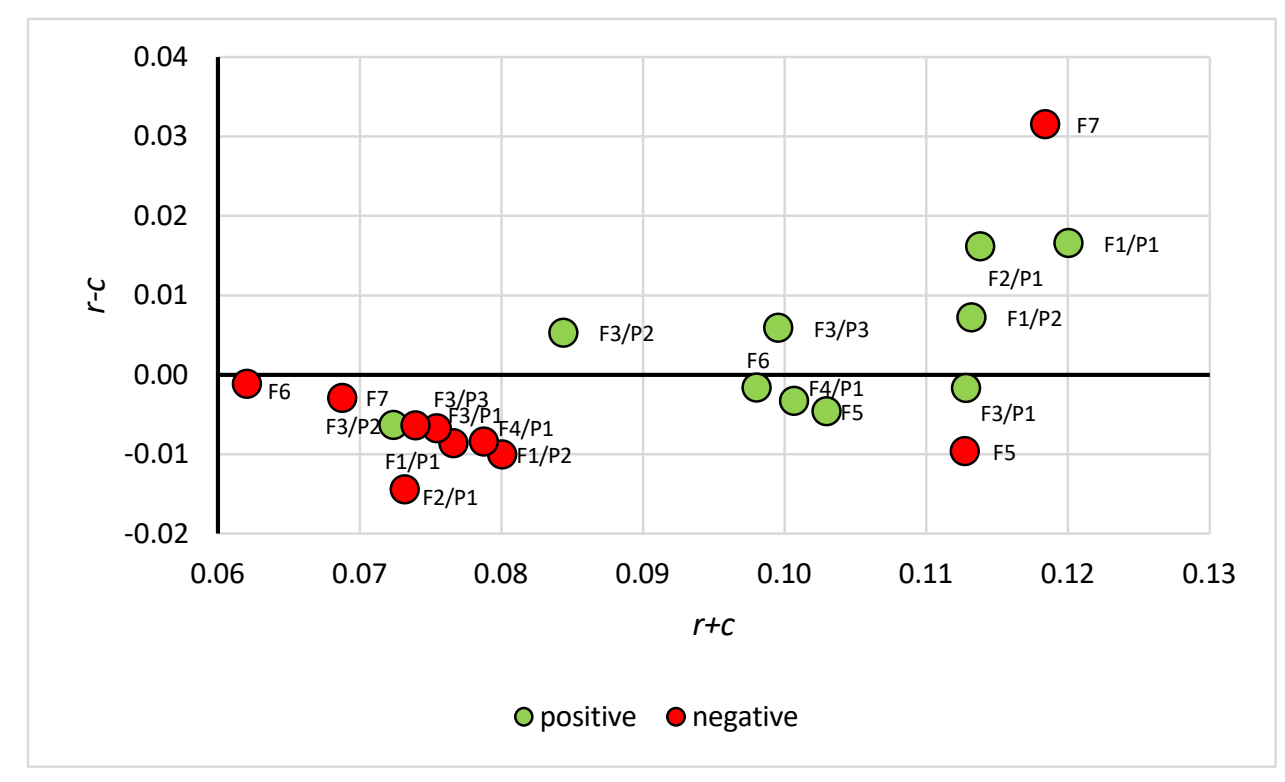

Figure 18. Influence map for criteria. 


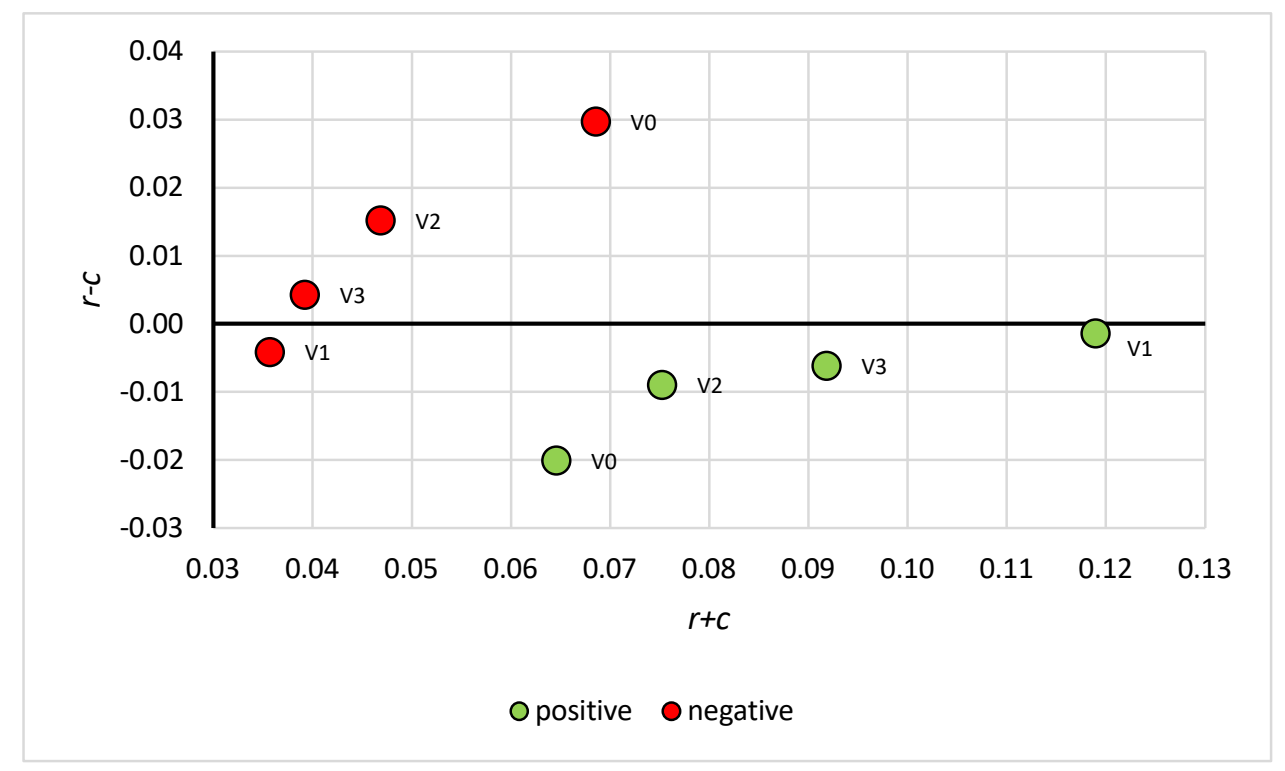

Figure 19. Influence map for variants.

\section{Conclusions}

The proposed network-based approach to the analysis of the problem presented in the paper creates a wide field of possibilities to take into account the relationship between the analysed sets of criteria and decision alternatives. Adopting a fuzzy extension of the analysis, as well as the adopted method of aggregating expert assessments, in turn, allows for uncertain input data.

The assessments of both positive and negative impacts of the variants analysed, as well as the results synthesised with the use of various formulas, clearly indicate alternative 1, a five-star hotel -as the one that best meets the given set of criteria. The current form of use has been rated the worst among the considered alternatives.

The analysis presented in the article concerns a specific historical building, and its results cannot be treated as appropriate for every adaptation project. Although the set of decision criteria used may correspond well to the problem of selecting the form of use of an adapted building in many cases, it is always recommended to consider whether it is sufficient and fully reflects the objectives of the project. Also, the set of variants presented in the paper cannot be treated as a closed set. Each building, with its specificity, size, previously performed function, social and cultural significance as well as commercial potential will have different possibilities of future use. The developer's expectations will always play a key role. Therefore, it is not possible to clearly define the sets of criteria and alternatives specific to each problem of adaptation of a historic building. Similarly, assessments of criteria, variants and interrelationships between them cannot be determined without specifying the problem first. Therefore, this paper is an example of how to proceed when selecting of the form of use of the adapted historical building in question. To a broader extent, it can be reproduced for buildings with similar characteristics to those presented. In the future, further operational verification of the presented approach is planned on other historic buildings with different characteristics. Further analyses also seem justified, assuming the possibility of the occurrence of several mutually complementary functions of buildings. This approach will require accounting for additional interdependencies between the decision alternatives themselves.

Author Contributions: Conceptualization, T.T., M.F.-C., E.R.-Z. and A.K.-K.; methodology, E.R.-Z., G.Ś., B.S., M.F.-C., A.K.-K., F.P. and T.T.; software, B.S.; validation, G.Ś. and B.S.; formal analysis, E.R.-Z., G.Ś. and B.S.; investigation, M.F.-C., A.K.-K., F.P. and T.T.; resources, E.R.-Z., G.S., M.F.-C., A.K.-K., F.P. and T.T.; data curation, E.R.-Z., B.S., G.S.., M.F.-C., A.K.-K., F.P. and T.T.; writing—original draft preparation, G.Ś., B.S., M.F.-C., A.K.-K. and F.P.; writing-review and editing, T.T., E.R.-Z., G.Ś. and B.S.; visualization, M.F.-C. and B.S.; supervision, T.T., 
E.R.-Z., M.F.-C. and A.K.-K.; project administration, T.T. and E.R.-Z.; funding acquisition, T.T. All authors have read and agreed to the published version of the manuscript.

Funding: This research received no external funding.

Acknowledgments: The authors thank the president of Akopol for making the "Stara Polana" facility available for research.

Conflicts of Interest: The authors declare no conflict of interest.

\section{References}

1. Radziszewska-Zielina, E.; Sladowski, G. Proposal of the Use of a Fuzzy Stochastic Network for the Preliminary Evaluation of the Feasibility of the Process of the Adaptation of a Historical Building to a Particular Form of Use. IOP Conf. Ser. Mater. Sci. Eng. 2017, 245, 072029. [CrossRef]

2. Nowogońska, B. Diagnoses in the Aging Process of Residential Buildings Constructed Using Traditional Technology. Buildings 2019, 9, 126. [CrossRef]

3. Skłodowski, M. Przykłady analizy wielokryterialnej w ocenie wartości i ochrony dziedzictwa kultury (Examples of Multi-Criteria Analysis in the Assessment of the Value and Protection of Cultural Heritage), ed. Szmygin, B., Systemy wartościowania dziedzictwa; Lubelskie Towarzystwo Naukowe (Lublin Scientific Association), Międzynarodowa Rada Ochrony Zabytków ICOMOS Politechnika Lubelska (ICOMOS International Council on Monuments and Sites, Lublin University of Technology): Warszawa, Poland, 2015; ISBN 978-83-7947-102-7.

4. Krawczyk, J. Ideał obiektywności wiedzy a początki wartościowania w konserwatorstwie (Ideal of the Objectivity of Knowledge Versus the Beginnings of Evaluation in Conservation), ed. Szmygin, B., Wartościowanie w ochronie i konserwacji zabytków (Evluation in); Lubelskie Towarzystwo Naukowe, Międzynarodowa Rada Ochrony Zabytków ICOMOS Politechnika Lubelska(ICOMOS International Council on Monuments and Sites, Lublin University of Technology): Warszawa, Poland, 2015; ISBN 9788379471027.

5. Ustinovičius, L.; Jakučionis, S. Application of multicriteria decision methods in restoration of buildings in the old town. Statyba 2000, 6, 227-236. [CrossRef]

6. Dytczak, M.; Ginda, G. Wybrane wielokryterialne metody wartościowania uwzględniajace trudno mierzalność cech zabytków (Selected Multi-criteria Evaluation Methods Taking into Account Qualities of Heritage Sites that are Difficult to Measure), ed. Szmygin; Lubelskie Towarzystwo Naukowe, Międzynarodowa Rada Ochrony Zabytków ICOMOS Politechnika Lubelska (ICOMOS International Council on Monuments and Sites, Lublin University of Technology): Warszawa, Poland, 2015; ISBN 9788379471027.

7. Dytczak, M. Wybrane Metody Rozwiazywania Wielokryterialnych Problemów Decyzyjnych w Budownictwie; Politechnika Opolska: Opole, Poland, 2010; ISBN 9788360691946.

8. Michnik, J. Weighted influence non-linear gauge system (WINGS)-An analysis method for the systems of interrelated components. Eur. J. Oper. Res. 2013, 228, 536-544. [CrossRef]

9. Paolillo, P.L.; Benedetti, A.; Baresi, U.; Terlizzi, L.; Graj, G. An assessment-based process for modifying the built fabric of historic centres: The case of Como in Lombardy. In Proceedings of the Lecture Notes in Computer Science (including subseries Lecture Notes in Artificial Intelligence and Lecture Notes in Bioinformatics); Springer: Berlin/Heidelberg, Germany, 2011; Volume 6782 LNCS, pp. 162-176.

10. Dutta, M.; Husain, Z. An application of Multicriteria Decision Making to built heritage. The case of Calcutta. J. Cult. Herit. 2009, 10, 237-243. [CrossRef]

11. Skłodowski, M.; Dytczak, M.; Szmelter, I. Multicriterial Valorization of a Monument Based on National Registry Data. In Proceedings of the EU-CHIC International Conference on Cultural Heritage, Split, Croatia, 29 May-1 June 2012; pp. 191-192.

12. Turskis, Z.; Zavadskas, E.K.; Kutut, V. A model based on ARAS-G and AHP methods for multiple criteria prioritizing of heritage value. Int. J. Inf. Technol. Decis. Mak. 2013, 12, 45-73. [CrossRef]

13. Kutut, V.; Zavadskas, E.K.; Lazauskas, M. Assessment of priority alternatives for preservation of historic buildings using model based on ARAS and AHP methods. Arch. Civ. Mech. Eng. 2014, 14, 287-294. [CrossRef]

14. Vodopivec, B.; Žarnić, R.; Tamošaitiene, J.; Lazauskas, M.; Šelih, J. Renovation priority ranking by multi-criteria assessment of architectural heritage: The case of castles. Int. J. Strateg. Prop. Manag. 2014, 18, 88-100. [CrossRef] 
15. Belniak, S. Bilansowanie funkcji w procesie przekształceń zespołów zabytkowych miast. In Zeszyty Naukowe/Akademia Ekonomiczna w Krakowie - nr 382; BazEkon-Yadda: Kraków, Poland, 1992.

16. Fusco Girard, L.; De Toro, P. Integrated spatial assessment: A multicriteria approach to sustainable development of cultural and environmental heritage in San Marco dei Cavoti, Italy. Cent. Eur. J. Oper. Res. 2007, 15, 281-299. [CrossRef]

17. Cerreta, M.; Panaro, S.; Cannatella, D. Multidimensional spatial decision-making process: Local shared values in action. In Proceedings of the Lecture Notes in Computer Science (including subseries Lecture Notes in Artificial Intelligence and Lecture Notes in Bioinformatics), Salvador de Bahia, Brazil, 18-21 June 2012; Springer: Berlin/Heidelberg, Germany; Volume 7334 LNCS, pp. 54-70.

18. Tupenaite, L.; Zavadskas, E.K.; Kaklauskas, A.; Turskis, Z.; Seniut, M. Multiple criteria assessment of alternatives for built and human environment renovation. J. Civ. Eng. Manag. 2010, 16, 257-266. [CrossRef]

19. Doulamis, A.; Kioussi, A.; Karoglou, M.; Matsatsinis, N.; Moropoulou, A. Collective intelligence in cultural heritage protection. In Proceedings of the Lecture Notes in Computer Science (including subseries Lecture Notes in Artificial Intelligence and Lecture Notes in Bioinformatics), Limassol, Cyprus, 29 October-3 November 2012; Springer: Berlin/Heidelberg, Germany; Volume 7616 LNCS, pp. 310-319.

20. Delegou, E.T.; Kiranoudis, C.; Sayas, J.; Moropoulou, A. DEVELOPING AN INTEGRATED DECISION MAKING SYSTEM FOR THE ASSESSMENT OF CLEANING INTERVENTIONS ON MARBLE ARCHITECTURAL SURFACES. In Proceedings of the 12th International Congress on the Deterioration and Conservation of Stone Columbia University, New York, NY, USA, 21-25 October 2012; pp. 1-11.

21. Arroyo Torralvo, F.; Villegas Sanchez, R. An application of multicriteria decision methodology to religious heritage conservation: The case of the Cathedral of Jerez de la Frontera (CADIZ). In Proceedings of the 6th European Symposium on Religious Art Restoration \& Conservation ESRARC'2014, Florence, Italy, 6-9 June 2014; pp. 9-11.

22. Zavadskas, E.K.; Antucheviciene, J. Development of an indicator model and ranking of sustainable revitalization alternatives of derelict property: A Lithuanian case study. Sustain. Dev. 2006, 14, 287-299. [CrossRef]

23. Zavadskas, E.K.; Antucheviciene, J. Multiple criteria evaluation of rural building's regeneration alternatives. Build. Environ. 2007, 42, 436-451. [CrossRef]

24. Fuentes, J.M. Methodological bases for documenting and reusing vernacular farm architecture. J. Cult. Herit. 2010, 11, 119-129. [CrossRef]

25. Wang, H.J.; Zeng, Z.T. A multi-objective decision-making process for reuse selection of historic buildings. Expert Syst. Appl. 2010, 37, 1241-1249. [CrossRef]

26. Giove, S.; Rosato, P.; Breil, M. A Multicriteria Approach for the Evaluation of the Sustainability of Re-Use of Historic Buildings in Venice. SSRN Electron. J. 2011. [CrossRef]

27. Giove, S.; Rosato, P.; Breil, M. An application of multicriteria decision making to built heritage. The redevelopment of Venice Arsenale. J. Multi-Criteria Decis. Anal. 2010, 17, 85-99. [CrossRef]

28. Ferretti, V.; Bottero, M.; Mondini, G. Decision making and cultural heritage: An application of the Multi-Attribute Value Theory for the reuse of historical buildings. J. Cult. Herit. 2014, 15, 644-655. [CrossRef]

29. Radziszewska-Zielina, E.; Śladowski, G. Supporting the selection of a variant of the adaptation of a historical building with the use of fuzzy modelling and structural analysis. J. Cult. Herit. 2017, 26, 53-63. [CrossRef]

30. Fedorczak-Cisak, M.; Kowalska-Koczwara, A.; Nering, K.; Pachla, F.; Radziszewska-Zielina, E.; Śladowski, G.; Tatara, T.; Ziarko, B. Evaluation of the criteria for selecting proposed variants of utility functions in the adaptation of historic regional architecture. Sustainability 2019, 11, 1094. [CrossRef]

31. Fedorczak-Cisak, M.; Kowalska, A.; Radziszewska-Zielina, E.; Śladowski, G.; Pachla, F.; Tatara, T. A multi-criteria approach for selecting the utility function of the historical building "Stara Polana" located in Zakopane. MATEC Web Conf. 2019, 262, 07002. [CrossRef]

32. Roberts, F.S. Applications of the theory of meaningfulness to psychology. J. Math. Psychol. 1985, 29, 311-332. [CrossRef]

33. Saaty, T.L. Decision Making with Dependence and Feedback: The Analytic Network Process; RWS Publications: Pittsburgh, PA, USA, 1996; ISBN 0-9620317-9-8.

34. Gabus, A.; Fontela, E. World Problems, An Invitation to Further Thought within the Framework of DEMATEL; Battelle Geneva Research Center: Geneva, Switzerland, 1972; pp. 1-8. 
35. Bouyssou, D.; Marchant, T.; Pirlot, M.; Tsoukias, A.; Vincke, P. Evaluation and Decision Models with Multiple Criteria: Stepping stones Volume 86; Springer Science \& Business Media: Berlin/Heidelberg, Germany, 2006.

36. Churchill, G.A. Badania Marketingowe: Podstawy Metodologiczne; Wydaw. Naukowe PWN: Warszawa, Poland, 2002; ISBN 9788301138202.

37. Zadeh, L.A. Fuzzy sets. Inf. Control 1965, 8, 338-353. [CrossRef]

38. Radziszewska-Zielina, E. Assessment methods of partnering relations of Polish, Slovak and Ukrainian construction enterprises with the fuzzy logic. Arch. Civ. Eng. 2011, 57, 87-118. [CrossRef]

39. Radziszewska-Zielina, E.; Szewczyk, B. Supporting partnering relations management in construction projects' implementation using AHP and Fuzzy AHP. Procedia Eng. 2016, 161, 1096-1100. [CrossRef]

40. Li, R.J. Fuzzy method in group decision making. Comput. Math. Appl. 1999, 38, 91-101. [CrossRef]

41. Pedrycz, W.; Gomide, F. Fuzzy Systems Engineering: Toward Human-Centric Computing; John Wiley: Hoboken, NJ, USA, 2007; ISBN 9780471788577.

42. Yager, R.R.; Filev, D.P. Essentials of Fuzzy Modeling and Control; Wiley: Hoboken, NJ, USA, 1994; ISBN 0471017612.

43. Bucoń, R.; Sobotka, A. Wyznaczanie zakresu remontu budynku mieszkalnego. Budownictwo i Architektura 2013, 12, 15-22.

44. Firlag, S.; Chmielewski, A. Defining the Polish nearly Zero Energy Building (nZEB) renovation standard-IOPscience. IOP Conf. Ser. Mater. Sci. Eng. 2018, 415, 1-8. [CrossRef]

45. Firlag, S. Cost-optimal plus energy building in a cold climate. Energies 2019, 12, 3841. [CrossRef]

46. DIRECTIVE (EU) 2018/844 OF THE EUROPEAN PARLIAMENT AND OF THE COUNCIL of 30 May 2018 Amending Directive 2010/31/EU on the Energy Performance of Buildings and Directive 2012/27/EU on Energy Efficiency (Text with EEA Relevance); EU: Brussels, Belgium, 2018.

47. Romanska-Zapala, A.; Bomberg, M.; Yarbrough, D.W. Buildings with environmental quality management: Part 4: A path to the future NZEB. J. Build. Phys. 2019, 43, 3-21. [CrossRef]

48. Yarbrough, D.W.; Bomberg, M.; Romanska-Zapala, A. Buildings with environmental quality management, part 3: From log houses to environmental quality management zero-energy buildings. J. Build. Phys. 2019, 42, 672-691. [CrossRef]

49. Romanska-Zapala, A.; Bomberg, M.; Dechnik, M.; Fedorczak-Cisak, M.; Furtak, M. On Preheating of the Outdoor Ventilation Air. Energies 2019, 13, 15. [CrossRef]

50. Romanska-Zapala, A.; Bomberg, M.; Fedorczak-Cisak, M.; Furtak, M.; Yarbrough, D.; Dechnik, M. Buildings with environmental quality management, part 2: Integration of hydronic heating/cooling with thermal mass. J. Build. Phys. 2018, 41, 397-417. [CrossRef]

51. PN-EN ISO-ISO 6946:2017-Building Components and Building Elements-Thermal Resistance and Thermal Transmittance -Calculation Methods; Polish Standardization Committee: Warsaw, Poland, 2017.

52. Rozporządzenie Ministra Infrastruktury i Budownictwa z dnia 14 listopada 2017 r. zmieniające rozporządzenie w sprawie warunków technicznych, jakim powinny odpowiadać budynki i ich usytuowanie (Regulation of the Minister of Infrastructure and Construction. Available online: http://prawo.sejm.gov.pl/ isap.nsf/DocDetails.xsp?id=WDU20170002285 (accessed on 19 April 2020).

53. Rozporządzenie Ministra Infrastruktury i Rozwoju z dnia 27 lutego 2015 r. w Sprawie Metodologii Wyznaczania Charakterystyki Energetycznej Budynku lub części Budynku oraz świadectw Charakterystyki Energetycznej (Regulation of the Minister of Infrastructure. Available online: http://prawo.sejm.gov.pl/isap. nsf/DocDetails.xsp?id=WDU20150000376 (accessed on 19 April 2020).

54. Description of the Leakage Test According to the Standard PN EN 13829. Available online: http://ceph.pibp. pl/wp-content/uploads/proba-szczelnosci_DE_04_09_str32-35.pdf (accessed on 20 April 2020).

55. Performing Thermovision Tests According to the Standard PN EN 13187. Available online: http://www. praze.pl/UserFiles/File/Pakiety/5/5.1/Zastosowanietermowizjiwbudownictwie-szkolenie2.pdf (accessed on 20 April 2020).

56. Kisilewicz, T. Passive control of indoor climate conditions in low energy buildings. Energy Procedia 2015, 78, 49-54. [CrossRef]

57. Dudzik, M.; Tomczyk, K.; Sieja, M. Optimal dynamic error formula for charge output accelerometer obtained by the neural network. In 2018 International Symposium on Electrical Machines; SME 2018; Institute of Electrical and Electronics Engineers Inc.: Piscataway, NJ, USA, 2018. 
58. Kisilewicz, T. Wpływ izolacji termicznej ścian na mikroklimat w budynkach w okresie letnim. Mater. Bud. 2015, 1, 112-115. [CrossRef]

59. Firlag, S.; Piasecki, M. NZEB Renovation Definition in a Heating Dominated Climate: Case Study of Poland. Appl. Sci. 2018, 8, 1605. [CrossRef]

60. Piasecki, M.; Kostyrko, K.; Pykacz, S. Indoor environmental quality assessment: Part 1: Choice of the indoor environmental quality sub-component models. J. Build. Phys. 2017, 41, 264-289. [CrossRef]

61. PN-EN ISO 7730: 2006. Ergonomics of The thermal Environment-Analytical Determination and Interpretation of Thermal Comfort Using the Calculation of PMV and PPD Indicators and Criteria of Local Thermal Comfort; Polish Standardization Committee: Warsaw, Poland, 2005.

62. PN ISO 7726: 2001. Ergonomics of the Thermal Environment. Instruments for Measuring Physical Quantities; Polish Standardization Committee: Warsaw, Poland, 2001.

63. ISO-ISO 9920:2007-Ergonomics of the Thermal Environment-Estimation of Thermal insulation and Water Vapour Resistance of a Clothing Ensemble. Available online: https://www.iso.org/standard/39257.html (accessed on 19 April 2020).

64. Sun, K.; Zhang, W. Combined Annoyance Assessment of Subway Train-Induced Structural Vibration and Ambient Noise. Shock Vib. 2016, 2016, 8. [CrossRef]

65. Ögren, M.; Gidlöf-Gunnarsson, A.; Smith, M.; Gustavsson, S.; Waye, K.P. Comparison of annoyance from railway noise and railway vibration. Int. J. Environ. Res. Public Health 2017, 14, 805. [CrossRef]

66. Radziszewska-Zielina, E.; Kania, E.; Śladowski, G. Problems of the selection of construction technology for structures in the centres of urban agglomerations. Archives Civ. Eng. 2018, 64, 55-71. [CrossRef]

67. Gierke, M.E.; Coerman, R.R. The biodynamics of human response to vibration and impact.-PubMed-NCBI. Ind. Med. Surg. 1963, 32, 30-32.

68. Dudzik, M.; Tomczyk, K.; Jagiello, A.S. Analysis of the error generated by the voltage output accelerometer using the optimal structure of an artificial neural network. In Proceedings of the 2018 19th International Conference on Research and Education in Mechatronics, REM 2018, Delft, The Netherlands, 7-8 June 2018; Institute of Electrical and Electronics Engineers Inc.: Piscataway, NJ, USA, 2018; pp. 7-11.

69. PN-B-02171: 2017-06. Evaluation of Human Exposure to Vibration in Buildings; Polish Standardization Committee: Warsaw, Poland, 2017.

70. Morioka, M.; Griffin, M.J. Difference thresholds for intensity perception of whole-body vertical vibration: Effect of frequency and magnitude. J. Acoust. Soc. Am. 2000, 107, 620-624. [CrossRef] [PubMed]

71. Okokon, E.O.; Yli-Tuomi, T.; Turunen, A.W.; Tiittanen, P.; Juutilainen, J.; Lanki, T. Traffic noise, noise annoyance and psychotropic medication use. Environ. Int. 2018, 119, 287-294. [CrossRef]

72. Beranek, L.L. Acoustic Measurements; American Institute of Physics: New York, NY, USA, 1949; ISBN 088-318590-3.

73. Bruel \& Kjaer. Environmental Noise Measurement; Bruel \& Kjaer: Nærum, Denmark, 2001.

74. Makarewicz, R.; Gołębiewski, R. Estimation of the long term average sound level from hourly average sound levels. Appl. Acoust. 2016, 111, 116-120. [CrossRef]

75. Malchaire, J. Sound Measuring Instruments; WHO: Brussels, Belgium, 1994.

76. Costa, J.J.L.; Nascimento, E.O.D.; Oliveira, L.N.D.; Caldas, L.V.E. Pressure sound level measurements at an educational environment in Goiânia, Goiás. J. Phys. Conf. Ser. 2017, 975, 012055. [CrossRef]

77. Park, T.; Kim, M.; Jang, C.; Choung, T.; Sim, K.-A.; Seo, D.; Chang, S. The Public Health Impact of Road-Traffic Noise in a Highly-Populated City, Republic of Korea: Annoyance and Sleep Disturbance. Sustainability 2018, 10, 2947. [CrossRef]

78. PN-EN 15251: 2012. Indoor Environmental Input Parameters for Design and Assessment of Energy Performance of Buildings Addressing Indoor Air Quality, Thermal Environment, Lighting and Acoustics; PKN: Warsaw, Poland, 2012.

79. PN-B-02151-2: 2018-01. Building Acoustics-Noise Protection in Buildings_Part 2: Requirements for Acceptable Sound Level in Rooms; Polish Standardization Committee: Warsaw, Poland, 2018.

80. Bogucki, D. Feasibility Study—Guide; PRESSCOM Sp. z o.o.: Wrocław, Poland, 2016.

81. Radziszewska-Zielina, E.; Rumin, R. Analysis Of The Profitability of Investment In Renewable Energy Sources On The Example of A Semi-Detached House. In International Conference on the Sustainable Energy and Environment Development; SEED, AGH, Center of Energy: Kraków, Poland, 2016; pp. 17-19. 
82. Affelt, W. Technical Heritage as a Part of Culture, Towards a Sustainable Heritage (Part 2), Protection of Monuments; Natl. Herit. Board Poland: Warsaw, Poland, 2009; pp. 53-82.

83. Radziszewska-Zielina, E.; Śladowski, G. Evaluation of historic building conversion options in the context of sustainable development. Czas. Tech. Bud. 2014, 2014, 153-164.

84. Korentz, J.; Nowogońska, B. Assessment of the life cycle of masonry walls in residential buildings. MATEC Web Conf. 2018, 174, 01025. [CrossRef]

(C) 2020 by the authors. Licensee MDPI, Basel, Switzerland. This article is an open access article distributed under the terms and conditions of the Creative Commons Attribution (CC BY) license (http://creativecommons.org/licenses/by/4.0/). 